\title{
The emission factor of volatile isoprenoids: stress, acclimation, and developmental responses
}

\author{
Ü. Niinemets ${ }^{1}$, A. Arneth ${ }^{2}$, U. Kuhn ${ }^{3}$, R. K. Monson ${ }^{4}$, J. Peñuelas ${ }^{5}$, and M. Staudt ${ }^{6}$ \\ ${ }^{1}$ Institute of Agricultural and Environmental Sciences, Estonian University of Life Sciences, Kreutzwaldi 1, \\ Tartu, 51014, Estonia \\ ${ }^{2}$ Division of Physical Geography and Ecosystem Analysis, Lund University, Sölvegatan 12, Lund, 22362, Sweden \\ ${ }^{3}$ Federal Research Station Agroscope Reckenholz-Taenikon, ART, Zuerich, Switzerland \\ ${ }^{4}$ Department of Ecology and Evolutionary Biology and Cooperative Institute for Research in Environmental Sciences, \\ University of Colorado, Boulder, CO 80309-0334, USA \\ ${ }^{5}$ Global Ecology Unit CSIC-CEAB-CREAF, Facultat de Ciències, Universitat Autònoma de Barcelona, \\ Bellaterra, 08193, Spain \\ ${ }^{6}$ Centre d'Ecologie Fonctionnelle et Evolutive (CEFE-CNRS), 1919 Route de Mende, Montpellier cedex 5, 34293, France
}

Received: 9 February 2010 - Published in Biogeosciences Discuss.: 2 March 2010

Revised: 20 June 2010 - Accepted: 7 July 2010 - Published: 20 July 2010

\begin{abstract}
The rate of constitutive isoprenoid emissions from plants is driven by plant emission capacity under specified environmental conditions ( $E_{\mathrm{S}}$, the emission factor) and by responsiveness of the emissions to instantaneous variations in environment. In models of isoprenoid emission, $E_{\mathrm{S}}$ has been often considered as intrinsic species-specific constant invariable in time and space. Here we analyze the variations in species-specific values of $E_{\mathrm{S}}$ under field conditions focusing on abiotic stresses, past environmental conditions and developmental processes. The reviewed studies highlight strong stress-driven, adaptive (previous temperature and light environment and growth $\mathrm{CO}_{2}$ concentration) and developmental (leaf age) variations in $E_{\mathrm{S}}$ values operating at medium to long time scales. These biological factors can alter species-specific $E_{\mathrm{S}}$ values by more than an order of magnitude. While the majority of models based on early concepts still ignore these important sources of variation, recent models are including some of the medium- to long-term controls. However, conceptually different strategies are being used for incorporation of these longer-term controls with important practical implications for parameterization and application of these models. This analysis emphasizes the need to include more biological realism in the isoprenoid emission models and also highlights the gaps in knowledge that require further experimental work to reduce the model uncertainties associated with biological sources of variation.
\end{abstract}

Correspondence to: $\ddot{U}$. Niinemets (ylo.niinemets@emu.ee)

\section{Introduction}

Accurate prediction of emissions of the very reactive plantgenerated volatile organic compound class - volatile isoprenoids - is highly relevant for reliable simulation of a number of atmospheric properties, including chemical reactivity and clearness (secondary organic aerosols, cloudiness) (Claeys et al., 2004; Curci et al., 2009; Fowler et al., 2009; Heald et al., 2008; Kanakidou et al., 2005; Kulmala et al., 2004; Mentel et al., 2009; Peñuelas and Staudt, 2010; Spracklen et al., 2008). The prediction of volatile isoprenoid emission fluxes is achieved by a variety of emission models applied at scales ranging from leaf to globe. These models are based either on Guenther et al. $(1991,1993)$ pivotal algorithms that phenomenologically described the instantaneous responses of isoprenoid emissions to key environmental drivers, light and temperature, or on process-based emission algorithms trying to link the emissions directly to enzyme kinetics and carbon metabolism (Arneth et al., 2007b; Martin et al., 2000; Niinemets et al., 1999, 2002b; Zimmer et al., 2000).

In all the existing emission models, predicted emission rates critically depend on the emission capacity that characterizes the plant potential for volatile isoprenoid formation under defined environmental conditions. In Guenther et al. $(1991,1993)$ type of models, the emission capacity is the average emission rate under standardized environmental conditions (typically leaf temperature of $30^{\circ} \mathrm{C}$ and quantum flux density of $1000 \mu \mathrm{mol} \mathrm{m}^{-2} \mathrm{~s}^{-1}$ ), also called the emission factor $\left(E_{\mathrm{S}}\right)$. In the process-based models, the emission capacity typically reflects the maximum activity of rate-limiting

Published by Copernicus Publications on behalf of the European Geosciences Union. 
enzymes such as isoprene and monoterpene synthases under given temperature (Martin et al., 2000; Niinemets et al., 1999, 2002b; Zimmer et al., 2000). In the latter type of models, the estimates of the emission capacity can be obtained from available $E_{\mathrm{S}}$ data under certain assumptions (e.g., Arneth et al., 2007b; Niinemets et al., 1999, 2002b).

Given the importance of $E_{S}$, many screening studies all over the world have been conducted to obtain $E_{\mathrm{S}}$ values for model parameterizations. Once reported, $E_{\mathrm{S}}$ estimates have been considered as constant in subsequent model estimates of plant isoprenoid emission fluxes (Guenther et al., 1994, 1995; Lamb et al., 1993; Simpson et al., 1995; Simpson et al., 1999) with the variability associated with $E_{\mathrm{S}}$ estimates and resulting uncertainties in model predictions analyzed in only very few cases (Guenther et al., 1994; Hanna et al., 2005). However, many of the existing $E_{S}$ estimates may not be wholly correct and can be misleading for a variety of reasons including conceptual, analytical and biological issues.

As demonstrated in the accompanying paper (Niinemets et al., 2010b), definition of $E_{\mathrm{S}}$ is dependent on the shape and stability, hence representativeness, of the assumed response curves, and therefore, $E_{\mathrm{S}}$ is largely a modeling concept defined within the given model framework. While $E_{\mathrm{S}}$ is defined in a relatively straightforward manner for isoprene, non-specific storage and induced emissions complicate the definition of the emission factor for mono- and sesquiterpenes (Niinemets et al., 2010b). Among the analytical problems, $E_{\mathrm{S}}$ estimation can critically depend on the enclosure and sampling techniques altering leaf environment during the measurements as well as on the efficiency of volatile sampling and detection (for analytical issues in determination of $E_{S}$ values see Ortega and Helmig (2008) and Ortega et al. (2008). Apart from the conceptual and analytical difficulties, vegetation has a huge capacity for developmental and adaptive modifications, resulting in strong temporal and spatial variations in $E_{\mathrm{S}}$. In particular, it has been observed that $E_{\mathrm{S}}$ is affected by leaf age and ontogeny (Mayrhofer et al., 2005; Monson et al., 1994; Wiberley et al., 2005), climatic conditions preceding the emission measurements (Blanch et al., 2010; Geron et al., 2000; Gray et al., 2006; Pétron et al., 2001; Sharkey et al., 1999; Staudt et al., 2003), environmental stress (Fang et al., 1996; Lavoir et al., 2009; Loreto and Schnitzler, 2010; Niinemets, 2010; Peñuelas and Staudt, 2010), growth $\mathrm{CO}_{2}$ concentration (Possell et al., 2005; Rosenstiel et al., 2003; Wilkinson et al., 2009) and acclimation of foliage to canopy light environment (Harley et al., 1996, 1997). While some recent models have attempted to include some of these factors (Ekberg et al., 2009; Guenther, 1999; Guenther et al., 1999, 2006; Keenan et al., 2009), many modeling exercises still do not consider vegetation as an adaptive system, leading to large uncertainties in emission inventories using static algorithms.

In this review, we analyze the alterations in constitutive isoprenoid emissions in response to biological factors and the implications for $E_{\mathrm{S}}$ determinations and isoprenoid emission model construction. In particular, we focus on environmental factors that influence longer-term responses of emissions from days to weeks and seasons, including the effects of stress, canopy environment, weather influences and dynamics in the atmospheric $\mathrm{CO}_{2}$ concentration, as these sources of variability are largely missing from the current emission models. We believe that the biological limitations can introduce at least as much variability in $E_{\mathrm{S}}$ values as conceptual and analytical problems (Niinemets et al., 2010b for an overview of conceptual issues). The analysis also highlights the key areas needed to be addressed by future research that aims to include more biological realism in models and thereby reduce the uncertainties in future model analyses. As biological aspects of induced emissions have recently been reviewed (Dicke and Baldwin, 2010; Loreto and Schnitzler, 2010; Niinemets, 2010), we deliberately focus here on the constitutive isoprenoid emissions.

\section{Biological sources of variability in emission inventories}

Most widely used volatile isoprenoid emission algorithms defined by Guenther et al. $(1991,1993)$ as modified by Wilkinson et al. (2009) describe the isoprenoid emission rate, $E$, as the product of standardized emission rate, $E_{\mathrm{S}}$, and the instantaneous responses of isoprenoid emissions to light, $f(Q)$, leaf temperature, $f\left(T_{\mathrm{L}}\right)$, and leaf intercellular $\mathrm{CO}_{2}$ concentration, $f\left(C_{\mathrm{i}}\right)$ :

$E=E_{\mathrm{S}} f(Q) f\left(T_{\mathrm{L}}\right) f\left(C_{\mathrm{i}}\right)$,

where the functions $f(Q), f\left(T_{\mathrm{L}}\right)$ and $f\left(C_{\mathrm{i}}\right)$ are normalized to 1.0 at standardized conditions used for $E_{\mathrm{S}}$ determination. Equation (1) provides a conceptually simple way to separate the emission controls that operate through instantaneous changes in environment and through longer term controls on $E_{\mathrm{S}}$. Drivers that can modify $E_{\mathrm{S}}$ values in time and space are environmental stress, past environmental conditions, and leaf age and seasonality. Modifications in $E_{\mathrm{S}}$ values due to these sources of variability are not typically considered in the emission models, except for a few cases (Boissard et al., 2008; Guenther et al., 1999, 2000, 2006; Karl et al., 2009; Keenan et al., 2009; Steinbrecher et al., 2009). As shown in the following, for many of the observed modifications in $E_{\mathrm{S}}$, we currently lack appropriate models or we lack information of the extent and time-kinetics of the $E_{\mathrm{S}}$ changes. Furthermore, biological sources of variability have been studied in only a few model species, making it difficult to derive parameter estimates for inclusion in large-scale models.

\subsection{Effects of stress on $E_{S}$}

Plants in field environments must frequently sustain stress periods of varying duration and severity. Abiotic and, in particular, biotic stress factors can lead to elicitation of volatile 
isoprenoid emissions in species non-emitting volatile isoprenoids constitutively, but can also modify the emission profiles in constitutive emitters (for reviews see Arneth and Niinemets, 2010; Loreto and Schnitzler, 2010; Niinemets, 2010). As discussed in the accompanying paper (Niinemets et al., 2010b), the induced emissions can critically alter the estimates of $E_{\mathrm{S}}$ and also require development of novel emission models.

Apart from the induction of new emissions, stress can also strongly alter the constitutive emissions and constitutive emissions can alter the sensitivity to stress (Vickers et al., 2009). So far, the influence of only a few stress factors on constitutive isoprenoid emissions has been studied. Among volatile isoprenoid vs. stress studies, limited water availability has obtained special attention, reflecting the importance of regular drought periods in Mediterranean and tropical dry forests and unpredictable episodic drought in many temperate forests. In addition, heat stress, alone or in combination with drought, often occurs in natural ecosystems (Hall, 1992; Hällgren et al., 1991; Peñuelas and Llusià, 2003). Here we focus on drought and heat stress effects on the constitutive isoprenoid emissions as these two factors have been studied in most systematic manner. We consider the immediate physiological stress responses and the acclimation (i.e., changes due to modified activity of terminal enzymes determining the emission capacity) observed during and after the stress. To highlight the richness of the stress responses, we also briefly review a number of other stresses and outline ways of considering the stresses in models.

\subsubsection{Influence of drought}

Drought vs. isoprenoid emission studies have demonstrated that drought effects on isoprenoid emissions crucially depend on the severity of drought (Niinemets, 2010). Mild drought stress does not strongly affect either isoprene (Pegoraro et al., 2004a; Pegoraro et al., 2004b; Sharkey and Loreto, 1993) or monoterpene (Lavoir et al., 2009; Peñuelas et al., 2009; Staudt et al., 2002) emissions. However, both isoprene and monoterpene emissions strongly decrease during prolonged drought (Bertin and Staudt, 1996; Brilli et al., 2007; Grote et al., 2009; Lavoir et al., 2009; Llusià and Peñuelas, 1998; Peñuelas et al., 2009; Sharkey and Loreto, 1993; Staudt et al., 2008; Staudt et al., 2002). As photosynthesis rate is significantly reduced already during a mild stress due to strong stomatal closure and reduction in intercellular $\mathrm{CO}_{2}$ concentration $\left(C_{\mathrm{i}}\right)$, the proportion of carbon lost as isoprene or monoterpenes increases significantly under conditions of soil moisture deficit (Fang et al., 1996; Llusià and Peñuelas, 1998; Niinemets et al., 2002a; Pegoraro et al., 2004b; Sharkey and Loreto, 1993).

To characterize the isoprene emission responses to changes in within-leaf $\mathrm{CO}_{2}$ concentration associated with immediate, rapid alterations of $\mathrm{CO}_{2}$ concentration either because of artificial alteration of ambient $\mathrm{CO}_{2}$ concentration or due to changes in stomatal openness, Wilkinson et al. (2009) have defined the $C_{\mathrm{i}}$ response function (Eq. 1$), f\left(C_{\mathrm{i}}\right)$ as:

$f\left(C_{\mathrm{i}}\right)=E_{\max }-\frac{E_{\max } C_{\mathrm{i}}^{h}}{C_{*}^{h}+C_{\mathrm{i}}^{h}}$,

where $E_{\max }$ is the asymptotic value at which a further reduction in $C_{\mathrm{i}}$ has an insignificant effect on the isoprene emission rate, and $C_{*}$ and $h$ are empirical scaling coefficients to calibrate the sigmoidal shape of the relationship between the isoprene emission rate and $C_{\mathrm{i}}$.

Can this response function be used to predict the isoprenoid emission responses to mild and severe drought? At current ambient $\mathrm{CO}_{2}$ concentration of ca. $385 \mu \mathrm{mol} \mathrm{mol}^{-1}$, mild drought stress typically results in reduction of $C_{\mathrm{i}}$ values in actively photosynthesizing leaves from ca. 250-330 $\mathrm{mol} \mathrm{mol}^{-1}$ to $200-250 \mu \mathrm{mol} \mathrm{mol}^{-1}$ (Flexas and Medrano, 2002; Medrano et al., 2002). According to the instantaneous $\mathrm{CO}_{2}$ response function (Eq. 2), applied over a finite $C_{\mathrm{i}}$ range of ca. $150-330 \mu \mathrm{mol} \mathrm{mol}^{-1}$, isoprene emission is relatively insensitive over this range or moderately increases at lower $C_{\mathrm{i}}$ (Wilkinson et al., 2009), likely explaining the insensitivity of isoprenoid emissions to mild stress (Lavoir et al., 2009; Peñuelas et al., 2009; Sharkey and Loreto, 1993; Staudt et al., 2002), or the moderately increased emissions occasionally observed under mild stress (Bertin and Staudt, 1996; Pegoraro et al., 2005; Staudt et al., 2008; Yani et al., 1993).

In contrast, severe drought results in reductions in $C_{\mathrm{i}}$ down to $100-150 \mu \mathrm{mol} \mathrm{mol}^{-1}, C_{\mathrm{i}}$ occasionally even reaching the photosynthetic compensation point under extreme drought (Flexas and Medrano, 2002; Medrano et al., 2002). Thus, strong reductions in intercellular $\mathrm{CO}_{2}$ concentration in response to the severe drought can explain the massive reduction, up to $10 \%$ to that before the stress of isoprene (Sharkey and Loreto, 1993) and monoterpene (Bertin and Staudt, 1996; Llusià and Peñuelas, 1998; Staudt et al., 2002) emissions. In addition, there is evidence of reduced isoprene synthase activity under severe drought (Brilli et al., 2007; Fortunati et al., 2008). Severe drought also partly uncouples isoprene synthesis from immediate photosynthetic carbon metabolism, implying that droughted plants use stored carbon fixed in periods prior to drought stress for formation of isoprene (Brilli et al., 2007; Fortunati et al., 2008). This means that the Eq. (2), in which the effects of $C_{\mathrm{i}}$ operate through immediate carbon metabolism, is not adequate in describing the severe drought stress effects.

The situation is further complicated by findings that after severe drought, isoprene and monoterpene emissions can be significantly higher compared to pre-stressed rates (Peñuelas et al., 2009; Sharkey and Loreto, 1993), although not always (Brilli et al., 2007; Fortunati et al., 2008). Such "overshoots" cannot currently be explained on the basis of immediate regulation of isoprenoid metabolism by $\mathrm{CO}_{2}$ availability. Enhanced expression of terminal enzymes responsible for isoprenoid emission during the sustained drought 
stress or during recovery may provide an explanation for such elevated emissions, but isoprenoid synthase activities have not been analyzed in "overshoot" studies. These observations collectively suggest that instantaneous emission vs. $C_{\mathrm{i}}$ responses can only partly explain the effects of prolonged drought periods on emissions. In addition to physiological short-term responses that can be likely explained by the $\mathrm{CO}_{2}$ response function (Eq. 2), changes in $E_{\mathrm{S}}$ values (emission capacity at any given $C_{\mathrm{i}}$ driven by isoprenoid synthase activities) and modifications in the carbon sources for isoprenoid production need consideration in prediction of the emissions under prolonged drought and after the drought.

So far, drought effects are mostly not considered in the existing isoprenoid emission models. Recently, the effects of drought were empirically included in MEGAN, assuming an hypothetical relationship between soil water content and isoprene emission after a threshold soil water content is reached (Guenther et al., 2006). In other models, effects of drought are included through drought effects on $C_{\mathrm{i}}$, carbon metabolism and photosynthetic electron transport similarly to the $C_{\mathrm{i}}$-response function (Arneth et al., 2007b; Grote et al., 2006; Niinemets et al., 2002b; for comparison of approaches to model drought effects on emissions see also Grote et al., 2009, 2010). However, as drought response involves also a longer-term component, an approach linking $E_{\mathrm{S}}$ to integrated drought dose, i.e., time-integrated plant water-status below the stress threshold water status, can provide a proxy to simulate such patterns similar to how past weather effects are included in the emission models (Sect. 2.3).

\subsubsection{Effects of heat stress}

Under natural conditions, high temperature is another key stress that may become especially severe in combination with drought when transpiratory water loss is reduced and leaf temperature rises significantly above the ambient air temperature. Sometimes leaf temperatures can exceed the ambient air temperatures even by more than $10^{\circ} \mathrm{C}$ (Hamerlynck and Knapp, 1994; Sharkey et al., 1996; Singsaas et al., 1999; Valladares and Niinemets, 2007).

The way the emissions respond to temperature depends on the duration of heat exposure. While short-term heat pulses, up to a few minutes, result in amplified emissions that can be explained by temperature-dependent increases in isoprene synthase activity (Fig. 1a), longer moderate heat stress lasting between tens of minutes to hours results in gradual reduction of the emission capacity, $E_{\mathrm{S}}$ (Fig. 1a, Singsaas and Sharkey, 2000). Reduced sensitivity of isoprene emissions to temperature can be associated with overall reduction of foliage metabolic activity (Sharkey and Seemann, 1989; Zhang et al., 2009; Zhang and Sharkey, 2009), and accordingly, reduced production of intermediates for isoprene synthesis. Engagement of alternate stored carbon sources may also explain the reduced temperature sensitivity of isoprene
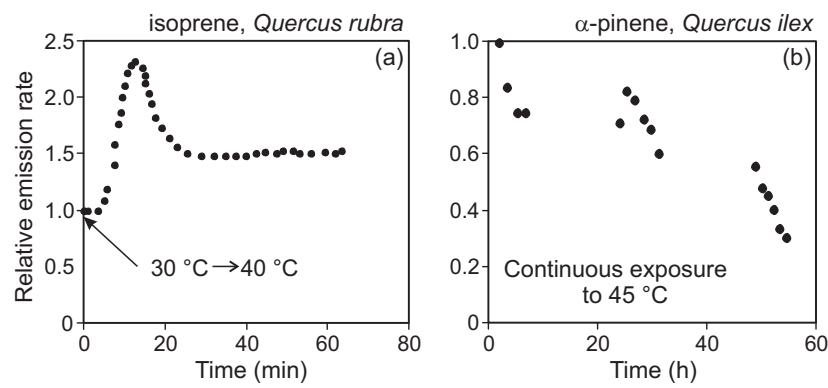

Fig. 1. Illustration of heat stress effects on isoprene (a) and monoterpene $\alpha$-pinene (b) emissions. Data in (a) are normalized with respect to the steady-state emission rate at $30^{\circ} \mathrm{C}$, while the data in (b) are normalized with respect to the emission rate before the heat stress. Modified from (a) Singsaas and Sharkey (2000) and (b) Staudt and Bertin (1998).

emissions, especially in combination with drought stress (Fortunati et al., 2008).

On the other hand, isoprene emission capacity increases during recovery after prolonged moderate heat periods lasting from a day to several days (e.g., Pétron et al., 2001; Sharkey et al., 1999), indicating acclimation to past temperature environment. Such an enhancement of isoprene emissions is most likely associated with an elevation of isoprene synthase activity (Mayrhofer et al., 2005; Wiberley et al., 2008).

Analogous responses have also been observed for monoterpene emissions (Fig. 1b, Loreto et al., 1998; Staudt and Bertin, 1998). However, in the case of monoterpenes with lower volatility, rapid temperature effects on the emissions (Ciccioli et al., 1997) can be due to the combined response of temperature on monoterpene synthase activity and evaporation of non-specifically stored monoterpenes (Niinemets et al., 2010b).

There is currently not enough physiological information to parameterize the time-dependent modifications in isoprenoid emission rates during heat stress. Thus, the emission rates are predicted using static emission response curves that are based on immediate effects of temperature on emissions, e.g., the rapid increase of isoprene emissions just after the increase of leaf temperature from $30^{\circ} \mathrm{C}$ to $40^{\circ} \mathrm{C}$ in Fig. 1a. As with drought, consideration of alternate carbon sources and modifications in enzymatic activities may be needed to include heat stress effects into the models. Differently from the responses during heat stress, modifications in $E_{\mathrm{S}}$ after moderate non-damaging heat stress have been successfully simulated using past temperature variations (Sect. 2.3).

\subsubsection{Other abiotic and biotic stresses and outlook}

Apart from these two key stresses, constitutive isoprenoid emissions are affected by many other stress factors including air pollutants such as ozone (e.g., Fares et al., 2006; Llusià et 
al., 2002; Loreto et al., 2004; Loreto and Velikova, 2001; Velikova et al., 2005), wounding (e.g., Funk et al., 1999; Loreto et al., 2000, 2006; Loreto and Sharkey, 1993), insect feeding (e.g., Brilli et al., 2009; Peñuelas et al., 2005; Staudt and Lhoutellier, 2007) and fungal infection (e.g., Anderson et al., 2000; Steindel et al., 2005). In general, these studies demonstrate a reduction in constitutive isoprenoid emission rates in species lacking specialized storage tissues. However, the plant response strongly depends on stress severity and duration (Niinemets, 2010 for a review), and increased emissions have been demonstrated in some cases, for instance in response to wounding (e.g., Loreto et al., 2006) or insect feeding (e.g., Peñuelas et al., 2005). Typically, the elevation of emissions after stress is associated with the release of novel compounds, reflecting elicitation of induced emissions (for these emissions see recent reviews by Holopainen and Gershenzon, 2010; Loreto and Schnitzler, 2010; Niinemets, 2010). Nevertheless, induced emissions may also consist of terpenoids that are under non-stressed conditions emitted constitutively (Staudt and Lhoutellier, 2007), making it difficult to separate between these two types of emissions.

In species with specialized storage tissues, enhanced emissions due to wounding or herbivory, at least temporarily, are commonly observed as the result of breakage and exposure to ambient air of the contents of these storage structures (Chen et al., 2009; Juuti et al., 1990; Kim, 2001; Litvak and Monson, 1998; Loreto et al., 2000; Priemé et al., 2000; Schade and Goldstein, 2003). Although such stress effects are currently ignored in the emission models, under natural conditions, plants essentially always suffer from moderate chronic biotic stresses, implying that damage of storage tissues frequently occur. As with non-storage emitters, biotic stress generally results in induced isoprenoid emissions in species with specialized storage structures as well, and these emissions can also be sometimes difficult to separate from the constitutive emissions (Huber et al., 2005; Litvak and Monson, 1998).

Overall, this evidence suggests that stress effects can prominently modify $E_{\mathrm{S}}$ values. Ignoring abiotic and biotic stress effects on $E_{\mathrm{S}}$ measurements as is common in field studies, especially in large screening programs, introduces large uncertainties in species-specific estimates of $E_{S}$. So far, information of many stress effects is rudimentary, and consequently, process-based models cannot yet be derived. However, information about the regulatory elements of key limiting enzymes such as isoprene synthase is gradually becoming available (Cinege et al., 2009; Loivamäki et al., 2007), implying that mechanistic models might be possible to develop in the near future. At any rate, it is important to characterize the presence of stress in field measurements. Standard physiological measures such as photosynthesis rate and stomatal conductance can provide important clues of the presence of environmental and biotic stresses, especially if baseline estimates of leaf physiological activity in non-stressed plants (e.g., Flexas and Medrano, 2002; Sharkey, 2005) or accepted reference values for given type of vegetation (e.g., Flexas and Medrano, 2002 for reference values of stomatal conductance) are available. In addition, measurements of stresselicited emissions of green leaf volatiles (various C6 aldehydes, also called lipoxygenase pathway volatiles) or methyl salicylate (Beauchamp et al., 2005; Fall et al., 1999; Heiden et al., 2003; Karl et al., 2008) can provide particularly useful information on stress evolution kinetics and strength. Both the measurements of net carbon gain and characteristic stress volatiles can be conducted at spatial scales ranging from single leaves and whole plants (as done conventionally) to ecosystems (e.g., Karl et al., 2008 for sensing of stress at ecosystem scale) and we call for inclusion of such measurements in standard protocols for estimation of biogenic volatile organic compound emissions.

\section{2 $E_{S}$ in relation to long-term variations in environment}

Many environmental drivers such as light and nutrient availability strongly vary within and among plant communities. There can be further important interactions among environmental drivers (Niinemets and Valladares, 2008 for a review). Effects of a variety of such environmental modifications on isoprenoid emissions have been studied (e.g., Peñuelas and Staudt, 2010). Here we analyze in detail the changes in isoprenoid emissions in response to variations in growth $\mathrm{CO}_{2}$ concentrations and in within-canopy environment to exemplify the potential magnitude of long-term environmental modifications on isoprenoid emissions.

Both these long-term sources of variation in emission rates are highly relevant to consider in the emission models. Inclusion of the $\mathrm{CO}_{2}$ effects is important to modeling that aims to understand how $\mathrm{CO}_{2}$ concentrations that have varied in the geological past, and those that are currently increasing with a rate of ca. 1.5-2.5 ppm/yr (www.esrl.noaa.gov/gmd/ ccgg/trends), influence isoprenoid emissions. On the other hand, as light gradients always occur in plant canopies, consideration of acclimation of isoprenoid emission potentials to within-canopy light environment is needed for accurate integration of canopy emission fluxes.

We further note that for simulation of emissions from a variety of ecosystems, it is important to consider also the soil nutrient effects on $E_{\mathrm{S}}$. So far, the majority of studies report a positive effect of $\mathrm{N}$-fertilization (or a positive correlation with foliar nitrogen) on $E_{\mathrm{S}}$ for isoprene, possibly mediated through a positive effect of $\mathrm{N}$ on overall foliage physiological activity, including the increases in foliage net assimilation rate and the capacity for volatile isoprenoid production (Ekberg et al., 2009; Harley et al., 1994; Litvak et al., 1996; Possell et al., 2004). In contrast, variable effects of $\mathrm{N}$ have been observed for monoterpene emission rates (Blanch et al., 2007; Lerdau et al., 1995; Staudt et al., 2001). In addition, other nutrients such as phosphorus can have differing effects on isoprenoid emissions (Fares et al., 2008). We refer to 


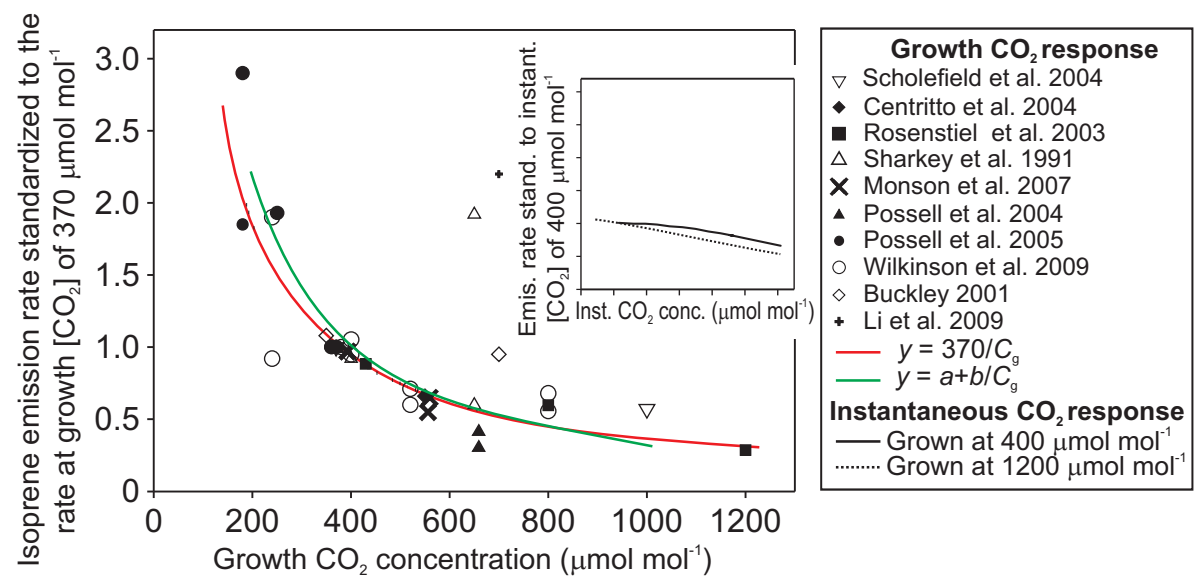

Fig. 2. Review of changes in isoprene emission rate under standardized conditions (leaf temperature of $30^{\circ} \mathrm{C}$, light intensity of $1000 \mu \mathrm{mol} \mathrm{m}{ }^{-2} \mathrm{~s}^{-1}$ and ambient $\mathrm{CO}_{2}$ concentration of $\left.370 \mu \mathrm{mol} \mathrm{mol}^{-1}\right)$ upon acclimation to different $\mathrm{CO}_{2}$ growth concentrations $\left(C_{\mathrm{g}}\right)$ (modified from Young et al., 2009) and comparison with the instantaneous $\mathrm{CO}_{2}$ (intercellular $\mathrm{CO}_{2}$ concentration, $C_{\mathrm{i}}$ ) response functions of

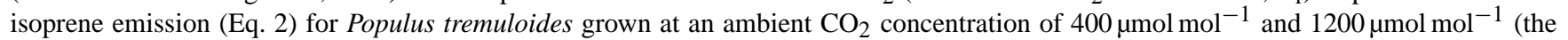
inset scale is the same as in the main panel, modified from Wilkinson et al., 2009). In the main panel, the data were expressed relative to the values measured in plants grown at the ambient $\mathrm{CO}_{2}$ concentration of $370 \mu \mathrm{mol} \mathrm{mol}^{-1}$, while the instantaneous $\mathrm{CO}_{2}$ response of isoprene emission was normalized with respect to an intercellular $\mathrm{CO}_{2}$ concentration of $400 \mu \mathrm{mol} \mathrm{mol}{ }^{-1}$. The following species were included in the analysis of the growth $\mathrm{CO}_{2}$ concentration effects: Arundo donax (Possell et al., 2005), Ginkgo biloba (Li et al., 2009), Eucalyptus globulus (Wilkinson et al., 2009), Liquidambar styraciflua (Monson et al., 2007; Wilkinson et al., 2009), Mucuna pruriens (Possell et al., 2005), Phragmites australis (Scholefield et al., 2004), Populus deltoides (Rosenstiel et al., 2003; Wilkinson et al., 2009), Populus x euroamericana (Centritto et al., 2004), Populus tremuloides (Monson et al., 2007; Sharkey et al., 1991; Wilkinson et al., 2009), Quercus chapmanii (Buckley, 2001), Quercus robur (Possell et al., 2004), Quercus rubra (Sharkey et al., 1991), and Quercus stellata (Monson et al., 2007). The red line denotes $y=370 / C_{\mathrm{g}}$ relationship previously used to simulate elevated $\mathrm{CO}_{2}$ effects on isoprene emissions (Arneth et al., 2007b), while the green line is the best fit relationship fitted to the data after leaving out the outlying observations for Ginkgo biloba (Li et al., 2009) and Quercus rubra (Sharkey et al., 1991) $\left(r^{2}=0.78\right)$.

Peñuelas and Staudt (2010) for a recent in-depth review of nutrient effects.

\subsubsection{Effects of growth $\mathrm{CO}_{2}$ environment on emissions in species without isoprenoid storage}

Apart from the instantaneous $\mathrm{CO}_{2}$ responses of isoprene emission (Eq. 2), an increasing number of studies have demonstrated acclimation of $E_{\mathrm{S}}$ to the long-term $\mathrm{CO}_{2}$ growth environment, visible as modification of the emission rates when assessed at the same intercellular $\mathrm{CO}_{2}$ concentration, $E_{\mathrm{S}, \mathrm{SCO} 2}$ (Fig. 2). Acclimation responses of plant carbon gain to ambient $\mathrm{CO}_{2}$ concentration are becoming routinely included in models of earth carbon balance (e.g., Gutschick, 2007; McMurtrie and Comins, 1996; Reynolds et al., 1996). However, growth $\mathrm{CO}_{2}$ effects have so far implicitly been considered in a very few cases in simulating volatile isoprenoid emissions under global change (Arneth et al., 2007a; Heald et al., 2009; Young et al., 2009).

For isoprene emissions, the acclimation responses observed in $E_{\mathrm{S}, \mathrm{SCO} 2}$ involve a significant decline in emissions in plants grown at higher $\mathrm{CO}_{2}$ atmospheres, while a strong increase in plants grown under below-ambient $\mathrm{CO}_{2}$ concentrations (Fig. 2, for overviews see Arneth et al., 2007b;
Peñuelas and Staudt, 2010; Young et al., 2009). For monoterpene emissions in species without specialized storage tissues, the response of $E_{\mathrm{S}, \mathrm{SCO} 2}$ to growth $\mathrm{CO}_{2}$ has been studied much less, but the available evidence also demonstrates a reduction of $E_{\mathrm{S}, \mathrm{SCO} 2}$ in plants grown under higher $\mathrm{CO}_{2}$ (Baraldi et al., 2004; Llorens et al., 2009; Loreto et al., 2001; Rapparini et al., 2004), although not always (Llorens et al., 2009; Loreto et al., 2001; Staudt et al., 2001). One study has further reported the increase in monoterpene $E_{\mathrm{S}, \mathrm{SCO} 2}$ in plants grown at $\mathrm{CO}_{2}$ concentrations below the ambient (Baraldi et al., 2004). Such similarity with the majority of isoprene studies is expected given the same chloroplastic 2C-methyl-D-erythritol 4-phosphate (MEP) pathway responsible for isoprene and monoterpene production.

Contrary to these reports, enhanced isoprene $E_{\mathrm{S}, \mathrm{SCO} 2}$ values were observed in plants with lifetime exposure to high $\mathrm{CO}_{2}$ in the vicinity of a natural $\mathrm{CO}_{2}$ spring (Tognetti et al., 1998). True statistical replication is principally not possible for $\mathrm{CO}_{2}$ spring studies, and thus, additional factors may have affected the patterns in Tognetti et al. (1998) study. However, higher isoprene emission rates were also observed under experimentally elevated $\mathrm{CO}_{2}$ in $\mathrm{Li}$ et al. (2009) and in one out of the two studied species in Sharkey and Loreto (1991). Enhanced monoterpene $E_{\mathrm{S}, \mathrm{SCO} 2}$ values in plants grown at 
higher $\mathrm{CO}_{2}$ environment were found in Staudt et al. (2001) and Llorens et al. (2009). These observations, contrasting the findings in the majority of other reports, are currently not understood, even if the data are analyzed at the same intercellular $\mathrm{CO}_{2}$ concentration to account for the short-term $\mathrm{CO}_{2}$ effects (Eq. 2).

To explain the reduction of isoprenoid $E_{\mathrm{S}, \mathrm{SCO} 2}$ values under high $\mathrm{CO}_{2}$ observed in the majority of studies, the same cellular mechanism as for the instantaneous $\mathrm{CO}_{2}$ response (Eq. 2) has been proposed, i.e., enhanced withdrawal of an isoprenoid intermediate, phosphoenolpyruvate (PEP), from chloroplasts and use of PEP in cytosol by PEP carboxylase (Rosenstiel et al., 2003). However, not only the literature reports are contrasting, but also the shape of instantaneous responses of isoprene emission to $\mathrm{CO}_{2}$ changes upon acclimation to growth $\mathrm{CO}_{2}$ (Wilkinson et al., 2009, Fig. 2 inset). Furthermore, the growth $\mathrm{CO}_{2}$ response is much stronger than the instantaneous $\mathrm{CO}_{2}$ response (Fig. 2 for the comparison). This suggests that factors other than or additional to substrate level control can be responsible for the observed patterns in $E_{\mathrm{S}, \mathrm{SCO} 2}$. Among these other factors, reduction in isoprene and monoterpene synthase activities may provide partial explanation for the reduction in the emission rates. In fact, a reduction in monoterpene synthase activity has been observed upon acclimation to elevated $\mathrm{CO}_{2}$ in the leaves of evergreen sclerophyll Quercus ilex (Loreto et al., 2001). Clearly, instantaneous (Eq. 2) and long-term responses need to be separately analyzed to simulate responsiveness of isoprenoid emissions to altered $\mathrm{CO}_{2}$ atmospheres. The situation is analogous to modeling $\mathrm{CO}_{2}$ effects on carbon gain. While instantaneous $\mathrm{CO}_{2}$ responses can be well described by the widely used Farquhar et al. (1980) photosynthesis model, photosynthetic acclimation to elevated $\mathrm{CO}_{2}$ is much more complex to simulate and requires consideration of additional feedbacks such as nutrient and water availabilities etc. (Gutschick, 2007 for a review).

\subsubsection{Growth $\mathrm{CO}_{2}$ effects in terpene-storing species}

In species where the emissions mainly rely on a large storage pool such as in conifers, no instantaneous effect of $\mathrm{CO}_{2}$ is expected, and the effects of altered growth $\mathrm{CO}_{2}$ concentration can occur through changes in total pool size and modifications in internal diffusion conductance for monoterpenes, e.g., through changes in resin duct to total leaf surface area ratio as well as through changes in resin duct epithelial permeability (Tingey et al., 1991 for a detailed model of monoterpene emission in storing species). Theoretical considerations based on tissue carbon/nitrogen $(\mathrm{C} / \mathrm{N})$ ratios predict stronger accumulation of secondary compounds such as monoterpenes when carbon availability is in excess of that required for growth, e.g., under elevated $\mathrm{CO}_{2}$ concentrations (Lerdau et al., 1994; Litvak et al., 2002; Peñuelas and Estiarte, 1998). This in turn suggests potentially higher emissions under elevated $\mathrm{CO}_{2}$ (Lerdau et al., 1994; Litvak et al., 2002; Peñuelas and Estiarte, 1998).

By now, some studies have reported a decrease rather than an increase in leaf monoterpene contents under elevated $\mathrm{CO}_{2}$ (Litvak et al., 2002; Räisänen et al., 2008a; Snow et al., 2003), while other studies have reported unaffected monoterpene contents (Constable et al., 1999; Peñuelas and Llusià, 1997), overall not agreeing with theoretical predictions. For the emissions, the studies have found a non-significant effect of elevated $\mathrm{CO}_{2}$ (Constable et al., 1999; Li et al., 2009; Llorens et al., 2009; Peñuelas and Llusià, 1997) or an increase or a decrease under high $\mathrm{CO}_{2}$, depending on species and time of sampling (Llorens et al., 2009). In Räisänen et al. (2008b), elevated $\mathrm{CO}_{2}$ alone did not affect the emissions, but a combination of high growth temperature and elevated $\mathrm{CO}_{2}$ resulted in greater emissions. Obviously, additional experimental work simultaneously analyzing the alterations in emissions, foliage anatomy and monoterpene pool sizes is needed to gain conclusive insight into growth $\mathrm{CO}_{2}$-driven changes in species with specialized terpene storage pools.

\subsubsection{Variations in light availability}

In plant canopies, there is an inherent variation in light availability, often more than 50-fold between the canopy top and bottom in dense stands (Niinemets, 2007 for a review). In addition, even in less densely vegetated ecosystems such as savanna-type woodlands, foliage is often strongly aggregated in the tree crowns, also bringing about large light availability gradients within the foliated plant parts (Asner et al., 1998). In addition to light, air and leaf temperatures increase with increasing light availability in tree canopies (Baldocchi et al., 2002; Niinemets and Valladares, 2004). Such long-term variations in environmental conditions are reflected in significant increases of isoprene emission rates per unit leaf area ( $\left.E_{\mathrm{S} \text {, area }}\right)$ from the canopy bottom to top (Harley et al., 1996, 1997; Niinemets et al., 1999). Analogous increases in $E_{\mathrm{S} \text {, area }}$ have been observed for monoterpenes in species without specialized storage tissues (Lenz et al., 1997; Niinemets et al., 2002a).

In general, the within-canopy range in $E_{\mathrm{S} \text {, area }}$ is more than an order of magnitude (Harley et al., 1996, 1997; Niinemets et al., 1999, 2002a). As $E_{\mathrm{S} \text {, area }}$ is the product of leaf dry mass per unit area $\left(M_{\mathrm{A}}\right)$ and $E_{\mathrm{S}}$ per unit leaf dry mass $\left(E_{\mathrm{S} \text {,mass }}\right)$, part of this extensive variation in $E_{\mathrm{S} \text {, area }}$ reflects modifications in leaf structure, i.e., increases in $M_{\mathrm{A}}$ with increasing light availability. Typically, $M_{\mathrm{A}}$ increases 2 -4-fold along the canopy light gradients (Niinemets, 2007 for a review), resulting in accumulation of isoprenoid synthesizing mesophyll cells per unit leaf area. Despite the importance of structural modifications, $E_{\mathrm{S} \text {,mass }}$ also varies 3-4-fold across the canopy light gradients (Niinemets et al., 2002a), indicating that the isoprenoid synthesis capacity of average leaf cells is also positively affected by light availability within the canopy. 
As light and temperature co-vary in plant canopies (Niinemets and Valladares, 2004), the question is whether the long-term variations in light or temperature drive changes in $E_{\mathrm{S}}$. This question is justified given that growth under higher temperatures also results in higher isoprene (Hanson and Sharkey, 2001b) and monoterpene emission rates (Staudt et al., 2003). However, studies with plants grown under different incident quantum flux densities in constant temperature environments have also demonstrated positive correlations between light availability and isoprene (Hanson and Sharkey, 2001b; Litvak et al., 1996) and monoterpene (Staudt et al., 2003) emission capacities. This evidence suggests that light alone can drive alterations in isoprenoid emission potential, although the role of temperature in within canopy variation in isoprenoid emission potentials cannot be ruled out.

Quantitative relationships with light availability or canopy leaf area index have not yet been developed. Nevertheless, within-canopy variation in $E_{\mathrm{S}}$ has been occasionally included in the emission models, varying $E_{\mathrm{S}}$ with cumulative leaf area index from the canopy top to the bottom (Guenther et al., 1999). However, in models that attempt to account for effects of growth environment, within-canopy variation of $E_{\mathrm{S}}$ is strongly reduced, since the variation is incorporated in long-term light response activity algorithms (Guenther et al., 1999). Models running with canopy-scale $E_{\mathrm{S}}$ values do not explicitly consider within-canopy variations, except when canopy-scale $E_{\mathrm{S}}$ values are constructed from leaf-level estimates (Guenther et al., 2006).

\section{3 $E_{\mathrm{S}}$ in relation to medium-term variations in environment}

In addition to the effects of long-term within-canopy variation in environment, light and temperature strongly fluctuate among consecutive days or groups of days. Abrupt alterations in environmental conditions such as suddenly improved light conditions after canopy gap formation in the understory or heat waves associated with synoptic weather systems also occur in nature. Experimental data demonstrate that $E_{\mathrm{S}}$ at any given location within the canopy is capable of acclimating to such environmental fluctuations (Funk et al., 2003; Hanson and Sharkey, 2001a; Sharkey et al., 1999). In fact, circadian and light-dependent regulatory elements have been observed for isoprene synthase, implying that the expression of isoprene synthase has the potential to respond to short-term stimuli (Cinege et al., 2009; Loivamäki et al., 2007; Wilkinson et al., 2006). Weather-dependent variations in isoprene emission capacity over periods of one to few days were best predicted by average temperature or light conditions of 12-48 $\mathrm{h}$ preceding the measurements (Ekberg et al., 2009; Funk et al., 2003; Geron et al., 2000; Sharkey et al., 1999; Simon et al., 2005; Wiedinmyer et al., 2005). Analogous relatively rapid acclimation responses have been reported for methylbutenol (Gray et al., 2006) and monoterpenes (Porcar-Castell et al., 2009; Staudt et al., 2003).
In addition to short-term responses to fluctuating light and temperature conditions, full acclimation to any given environmental modification can take much longer, especially for profound alterations in environment. For isoprene emissions, 4-6 days are needed to fully respond to a step change in environmental conditions (Hanson and Sharkey, 2001a; Pétron et al., 2001). For monoterpene emission, it has further been demonstrated that the response kinetics differ for the increase (Fig. 3a) and decrease (Fig. 3b) of light intensity and temperature (Staudt et al., 2003). While full acclimation to the increased light and temperature took ca. 10 days (Fig. 3a), the response to reduced light and temperature took almost 40 days (Fig. 3b). Such asymmetric responses mean that the use of simple correlations of $E_{\mathrm{S}}$ with average values of temperature from the preceding few days are likely in error. In fact, the correlations observed with past environmental drivers are often scattered (Funk et al., 2003; Geron et al., 2000), possibly reflecting the different time kinetics for the rise and reduction of emission capacities in response to environmental alterations.

Although using an average value of $E_{\mathrm{S}}$ during a certain time period may realistically estimate the average emission rate during this time period, such an approach will overestimate the emissions during some periods of the simulation and underestimate during other periods, with the magnitude of the errors depending on the degree of fluctuation of environment. So far, the influence of preceding environmental conditions is included in only very few models. In MEGAN (Guenther et al., 2006), the temperature response function used in Eq. (1) is modified in dependence on the average temperature of past $24 \mathrm{~h}$ and past 10 days to consider longerterm acclimation responses (s. seasonality in Sect. 2.4). In this new model formulation (Guenther et al., 2006), the temperature response function, $f\left(T_{\mathrm{L}}\right)$, modified this way, does generally not equal 1.0 under typical standard temperature of $T_{\mathrm{L}}=30^{\circ} \mathrm{C}$. Apart from temperature response function, the light response function is also modified in dependence on past $24 \mathrm{~h}$ and $240 \mathrm{~h}$ light environment (Guenther et al., 2006). Ekberg et al. (2009), recently proposed an empirical relationship between $48 \mathrm{~h}$ average temperature and $E_{\mathrm{S}}$ to simulate the past weather influences on isoprene emission (Ekberg et al., 2009, Fig. 4), implicitly arguing that in the case of field observations, it is not possible to separate effects of past temperature and light conditions since these strongly co-vary. The simulations of the influences of temperature history on temporal dynamics with both models demonstrate significant effects of past weather conditions on the emissions, but also that the function used to describe the past weather can significantly alter the predicted emission fluxes (Fig. 4).

Apart from the need for consensus description of past climate effects on emissions, there are other difficulties associated with the existing models. First, the speed of acclimation and response curve shapes can vary between species of the same biome (Ekberg et al., 2009) and possibly between different biomes. So far, the models use a constant 

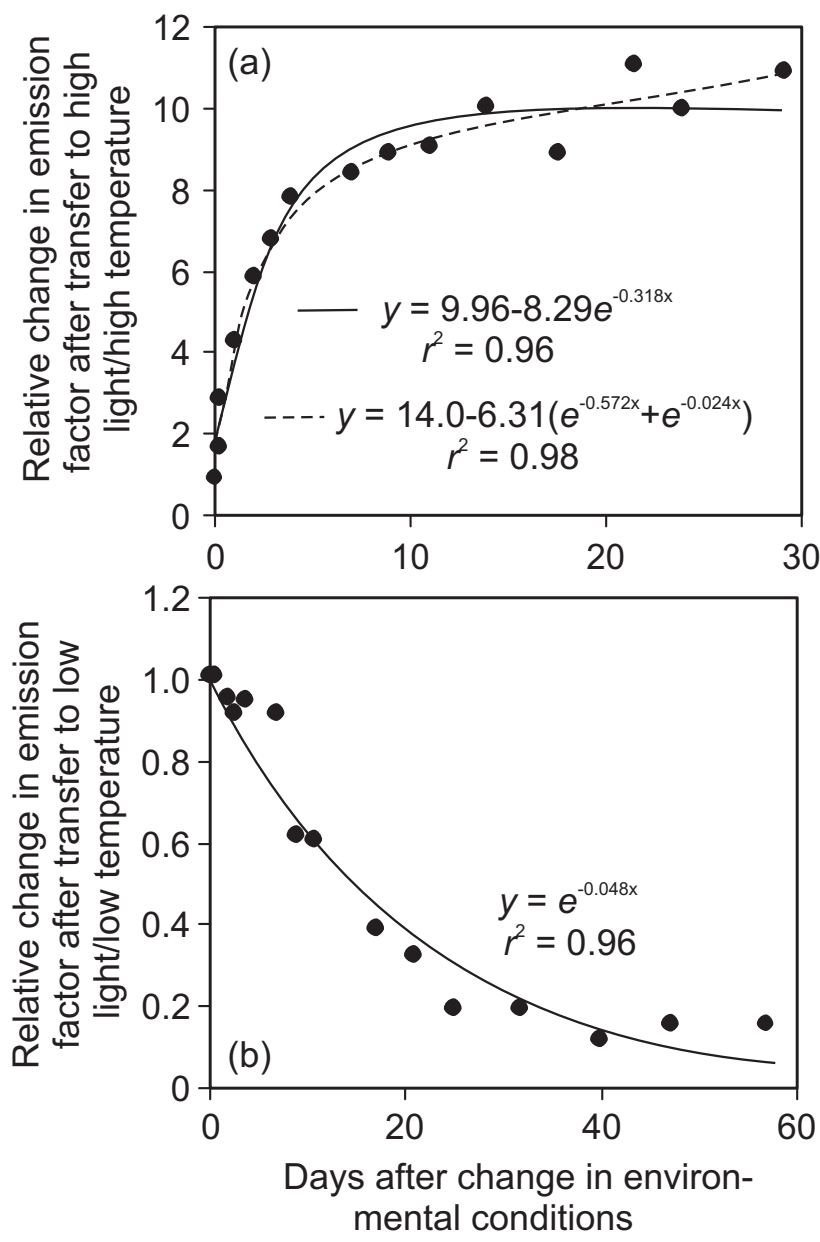

Fig. 3. Example of the acclimation kinetics of the monoterpene emission factor in Mediterranean evergreen sclerophyll Quercus ilex after transfer of plants from (a) moderate light (quantum flux density, $\left.Q=300 \mu \mathrm{mol} \mathrm{m} \mathrm{m}^{-2} \mathrm{~s}^{-1}\right)$ and low temperature $\left(10^{\circ} \mathrm{C}\right.$ night $/ 20^{\circ} \mathrm{C}$ day) to high light $\left(Q=1100 \mu \mathrm{mol} \mathrm{m}^{-2} \mathrm{~s}^{-1}\right)$ and warm temperature $\left(20^{\circ} \mathrm{C} \mathrm{night} / 30^{\circ} \mathrm{C}\right.$ day $)$, and after an opposite transfer (b). The emission factor was measured at leaf temperature of $25^{\circ} \mathrm{C}$ and incident quantum flux density of $900 \mu \mathrm{mol} \mathrm{m}^{-2} \mathrm{~s}^{-1}$ after reaching the steady state ( $\geq 60 \mathrm{~min}$ ) under these assay conditions. The data were fitted by exponential decay functions. In (a) double exponential model (dashed line) improved the fit, suggesting that the acclimation consists of several processes with different timekinetics. The half-time for the response, $\tau=\ln (2) / k$, where $k$ is the exponential decay constant. The reduction of the emission factor after transfer to moderate light/low temperature occurs with slower time kinetics $\tau=14.4 \mathrm{~d}$ than the increase of the emissions after transfer to high light/high temperature (for double-exponential model, the shorter $\tau=1.21 \mathrm{~d}$, and for single-exponential model $\tau=2.18 \mathrm{~d}$ ). Data modified from Staudt et al. (2003). past climate function for ecosystems as divergent as tropics and tundra (Ekberg et al., 2009; Guenther et al., 2006). In addition, past environmental effects in large scale models are only considered for isoprene. Yet, the temporal kinetics can be different for isoprene (Funk et al., 2003; Geron et al., 2000; Hanson and Sharkey, 2001a; Sharkey et al., 1999) and monoterpenes (Porcar-Castell et al., 2009; Staudt et al., 2003). Clearly more experimental work is needed to gain insight into the variations of past weather vs. isoprene and monoterpene emission responses.

\subsection{Seasonal and age-dependent variations in $E_{\mathrm{S}}$}

\subsubsection{Variations driven by environmental modifications, foliage development, senescence and stress}

Short-term environmental fluctuations between the days are superimposed on longer-term seasonal and developmental variations. Isoprene synthase activity increases gradually until full leaf maturation and decreases thereafter with the onset of leaf senescence (Schnitzler et al., 1997), reflecting seasonal variations in the expression of isoprene synthase and other enzymes of chloroplastic isoprenoid synthesis pathway (MEP pathway, Mayrhofer et al., 2005). Analogous developmental modifications have been observed for monoterpene synthase activity in species without specialized storage (Fischbach et al., 2002). The changes in limiting enzyme activity are accompanied by strong seasonal modifications in isoprene and monoterpene emissions with a maximum during the active growth period, and decline in senescing leaves (Fig. 5, Boissard et al., 2001; Ciccioli et al., 2001; Fischbach et al., 2002; Fuentes and Wang, 1999; Geron et al., 2000; Keenan et al., 2009; Kuhn et al., 2004; Mayrhofer et al., 2005; Sabillón and Cremades, 2001; Schnitzler et al., 1997). It has been demonstrated that lack of consideration of such longer-term controls results in overall low explanatory power of isoprene emission models (Boissard et al., 2008), implying that it is highly relevant to gain mechanistic insight into the determinants of seasonality.

Because environmental conditions vary during the season, in principle, the same mechanisms responsible for shorterterm changes can be considered operational (Sect. 2.3), i.e. the seasonal variations in $E_{\mathrm{S}}$ can be associated with seasonal changes in temperature and light (Lehning et al., 2001; Mayrhofer et al., 2005). In fact, in fully-developed nonsenescent leaves, seasonal modifications in isoprenoid $E_{\mathrm{S}}$ values were correlated with seasonal changes in light and temperature (Geron et al., 2000; Grote et al., 2009; Lehning et al., 2001; Mayrhofer et al., 2005), demonstrating that variations in environmental drivers during the season play a major role in the seasonality of isoprenoid emissions.

Apart from immediate environmental effects operating on fully mature non-senescent leaves in seasonal climates, the physiological activity of foliage varies in dependence on leaf ontogenetic stage, increasing rapidly in developing leaves 

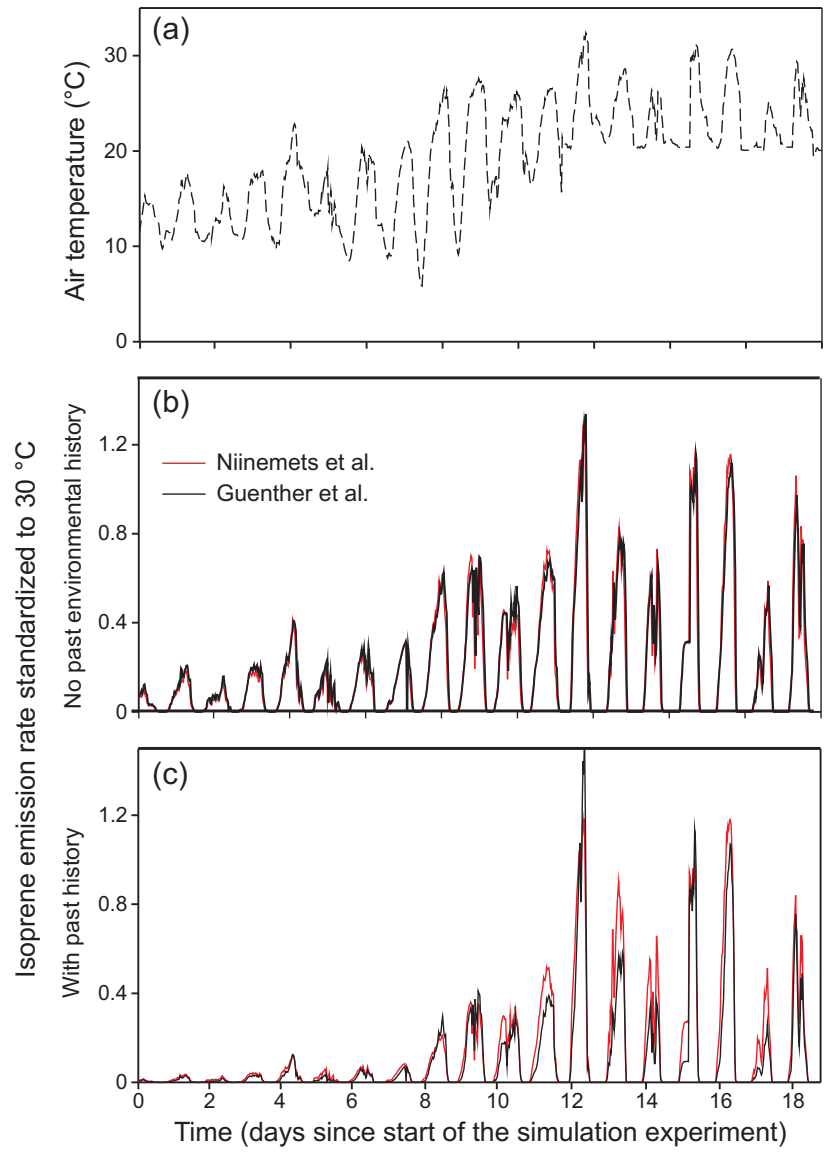

Fig. 4. Simulated temporal variation in isoprene emissions normalized to the rate at $30^{\circ} \mathrm{C}$ in response to typical diurnal variations in temperature in continental temperate environments (a). The simulations without temperature history (b) were conducted with the algorithms of Guenther et al. (1993, Eq. 1, black line) and Niinemets et al. (1999, red line) that links the isoprene emissions to the rates of photosynthetic electron transport. In the latter simulation, electron flow was provided from the photosynthesis model of Farquhar et al. (1982) and assuming fully open stomata, and adjusting the fraction of electrons going into isoprene synthesis pathway such that the emission rate under standardized conditions equaled that in Guenther et al. (1993). In (c), the emissions were simulated by the same two models, but for Guenther et al. (1993) algorithms, the past temperature and radiation history was considered as in Guenther et al. (2006, MEGAN), and the past temperature history for the Niinemets et al. (1999) model as found in Ekberg et al. (2009). The latter was from a study in cool growth environment and the exponential function was re-scaled to the same common temperature as used in the MEGAN temperature-history algorithm. In MEGAN, the optimum temperature of the isoprene response function $(f(T)$ in Eq. 1) depends linearly on the previous temperature of the past $240 \mathrm{~h}$, while the standardized emission rate depends exponentially on the temperature of the past 24 and $240 \mathrm{~h}$ (Guenther et al., 2006). In Ekberg et al. (2009), the standardized isoprene emission rate depends exponentially on the previous temperature of the past $48 \mathrm{~h}$.

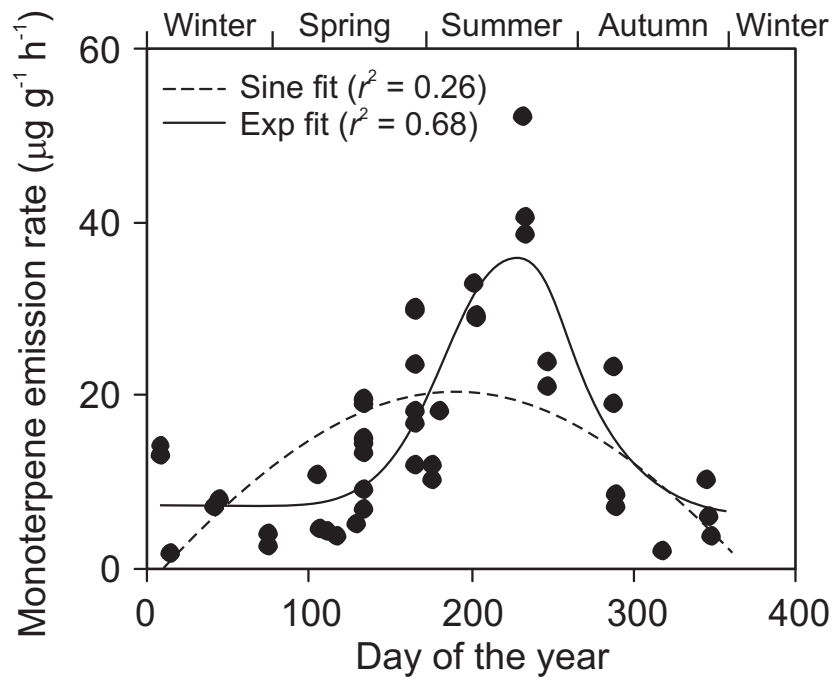

Fig. 5. Seasonal variation in standardized monoterpene emission rate (leaf temperature of $30^{\circ} \mathrm{C}$ and light intensity of $1000 \mu \mathrm{mol} \mathrm{m}^{-2} \mathrm{~s}^{-1}$ ) in Mediterranean evergreen sclerophyll Quercus ilex. Data (filled symbols) were combined from several independent sources (Bertin et al., 1997; Kesselmeier et al., 1997, 1998; Llusià and Peñuelas, 2000; Owen et al., 1997; Sabillón and Cremades, 2001; Staudt et al., 2002, 2004; Street et al., $1997)$ and $E_{S}$ vs. day of the year relationships were fitted either by a symmetric sine function or an asymmetric exponential function (Keenan et al., 2009). The sine function was defined as $y=a^{*} \sin [(b+x) * 180 / 365]+c * \sin [(d+x) * 180 / 365]$, where $a-d$ are empirical parameters. The exponential function was defined as $y=a_{1}+a_{2} e^{\left(-\frac{\left(x-a_{3}\right)^{2}}{a_{4}}\right)}$, where $a_{1}-a_{4}$ are empirical parameters; this function allows to parameterize asymmetric seasonal variation patterns (Keenan et al., 2009 for further details). Although the symmetric sine or second order polynomial functions are often used to characterize the seasonal changes (Hargreaves et al., 2000; Stolwijk et al., 1999), the seasonal variation in $E_{\mathrm{S}}$ was clearly asymmetric.

and decreasing in senescing leaves undergoing programmed cell death (e.g., Grassi et al., 2005; Niinemets et al., 2004, 2010a; Shesták et al., 1985). As isoprene synthase is not expressed in very young leaves, the leaves achieve photosynthetic competence earlier than the capacity for isoprene emission (Grinspoon et al., 1991; Mayrhofer et al., 2005; Wiberley et al., 2005). The lag between the onset of photosynthesis, and the capacity of the leaves to emit isoprene is a few days in hot tropical environments where the temperature environment is relatively stable (Kuhn et al., 2004). The lag increases to weeks in cooler seasonal temperate environments where leaf developmental periods are associated with strong increases in temperature (Monson et al., 1994; Schnitzler et al., 1997; Wiberley et al., 2005). Experimental increase of the ambient temperature has been shown to result in earlier onset of isoprene emission in leaves of the same developmental stage (Wiberley et al., 2005), suggesting that 
the onset of isoprene emission is at least partly under environmental control.

In deciduous species in seasonal climates, reductions in day length (light availability) and temperature are also associated with the onset of leaf senescence, leading to rapid reductions in foliage photosynthetic activity (Grassi et al., 2005; Niinemets et al., 2004) and coordinated degradation of leaf function (Keskitalo et al., 2005). Overall decline in leaf physiological activity is also associated with strong reductions in foliage isoprene emission rates (Lehning et al., 2001; Mayrhofer et al., 2005; Sun et al., 2009). The onset of senescence is both under environmental (temperature) and photoperiodic control (Fracheboud et al., 2009; Rosenthal and Camm, 1996, 1997), but once elicited, is typically not reversible (van Doorn and Woltering, 2004). This implies that alterations in environmental conditions, e.g. autumn warm spells, not necessarily affect $E_{\mathrm{S}}$, and the decline of $E_{\mathrm{S}}$ in senescing leaves is largely independent of environmental modifications (Sun et al., 2009).

In species with foliage longevities extending over several growing seasons, senescence of older foliage can occur throughout the year, although it is often more frequent during new foliage growth and development (Bargali and Singh, 1997; Gholz et al., 1991; Pook, 1984). However, older non-senescent foliage becomes gradually shaded due to new foliage formation and expansion (Brooks et al., 1994; Niinemets et al., 2006). In Quercus ilex, it has been demonstrated that 1-yr-old leaves intercept ca. 30\% less light than the current-year leaves, and more than 3-yr-old leaves intercept even ca. $80 \%$ less light than they intercepted during their formation (Niinemets et al., 2006). Until now, agedependent changes of isoprenoid emission capacity of nonsenescent leaves in species with foliage life-span of more than one season have not been studied extensively. Reductions of light availability due to enhanced within-canopy shading suggest that isoprenoid emission capacity declines with increasing leaf age (Sects. 2.2.3 and 2.3). In fact, a lower monoterpene $E_{\mathrm{S}}$ estimate has been obtained for 1-yrold leaves of $Q$. ilex relative to the current-year leaves (Staudt et al., 2003), and this change has been associated with reductions in monoterpene synthase activity (Fischbach et al., 2002). However, no significant difference between current and 1-yr-old leaves was found in the same species in another study (Lavoir et al., 2009), although the trend was similar to Staudt et al. (2003). Besides the changes in physiological activity due to enhanced shading, there is also evidence of lower photosynthetic activity of older foliage at any given light availability (Niinemets et al., 2006), but no studies have so far examined such modifications in $E_{\mathrm{S}}$ values of older foliage under controlled (or specified) light availability. Clearly more experimental work is needed to characterize the variation in $E_{\mathrm{S}}$ values of older foliage due to enhanced shading as well as time-dependent reductions of foliage physiological activity.

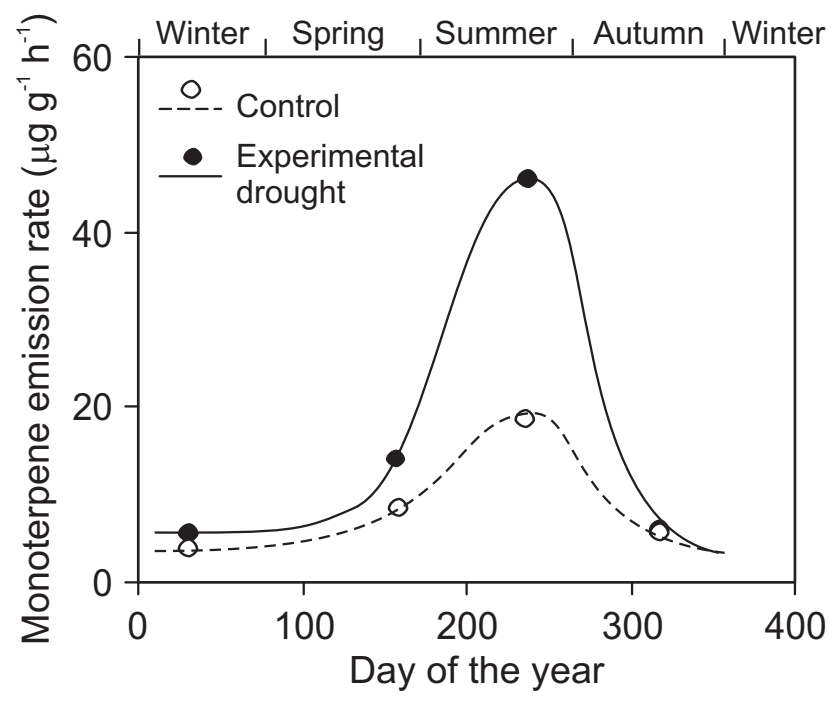

Fig. 6. Interaction of drought stress with seasonal variation in standardized monoterpene emission rate (leaf temperature of $30^{\circ} \mathrm{C}$ and light intensity of $1000 \mu \mathrm{mol} \mathrm{m} \mathrm{m}^{-2} \mathrm{~s}^{-1}$ ) in Quercus ilex. The experimental drought treatment in the Mediterranean $Q$. ilex forest included partial rain and runoff exclusions and resulted in a reduction in soil water availability by ca. $25 \%$ in all seasons except the summer hot and dry season, where the soil water availability was similar in both control and drought treatments. Thus, drought prior to summer season was responsible for enhanced emission rates in summer in the drought experiment. Average data for the growing seasons 2003 and 2005 were fitted by the exponential asymmetric function as in Fig. 5 (modified from Llusià et al., 2010).

Long-term variations in factors other than incident light and air temperature can occur during the season. In particular, as discussed in Sect. 2.1.1, seasonal drought can importantly affect the emission rates. While immediate drought effects on the emission rates can be explained on the basis of modifications in intercellular $\mathrm{CO}_{2}$ concentration (Sect. 2.1.1), long-term drought effect, involving acclimation and causing variations in $E_{\mathrm{S}}$ may be difficult to separate from changes in $E_{S}$ driven by seasonal variations in light and temperature and leaf ontogeny alone. There is evidence that the history of drought can affect the seasonal $E_{\mathrm{S}}$ responses (Fig. 6). For example, $E_{\mathrm{S}}$ was vastly increased during the water-limited period of the year in Quercus ilex plants subject to a more severe drought stress compared with the control treatment. Variations in the sensitivity to seasonal drought and the severity of drought sustained in different sites can provide an explanation for significant interspecific variability in seasonal responses of $E_{\mathrm{S}}$ in the field (Keenan et al., 2009).

In addition to the developmental, environmental and stress-dependent modifications of isoprenoid emission potentials of single cells, a further complication with developmental modifications in isoprenoid emission capacity is that leaf structure $\left(M_{\mathrm{A}}\right)$ also varies during the season. In 
particular, $M_{\mathrm{A}}$ strongly increases in developing leaves, and somewhat decreases in senescing leaves (Grassi and Magnani, 2005; Niinemets et al., 2004; Wilson et al., 2001). Thus, part of the seasonal variation in $E_{\mathrm{S} \text {,area }}$ is structural rather than entirely associated with the alterations in physiological activity of single cells. Accordingly, in addition to changes of the expression of isoprenoid synthase activities, information of alterations in leaf structure is needed for mechanistic consideration of seasonality of isoprenoid emissions in the models.

\subsubsection{Including seasonality and age effects in emission models}

The previous section indicated that seasonal variations in $E_{\mathrm{S}}$ entail changes due to foliage development, seasonal variations in environmental drivers, and senescence and may additionally involve long-term stress effects. We suggest that all these aspects should be addressed in mechanistic models seeking to describe seasonal variations in $E_{\mathrm{S}}$. In species with foliage longevity of more than one growing season, foliage shading and time-dependent changes of physiological activity of non-senescent leaves may further importantly alter $E_{\mathrm{S}}$.

Several approaches have been proposed for incorporation of seasonality in models. Schnitzler et al. (1997) included an additional modifier in Eq. (1), the seasonality function. In such an approach, $E_{\mathrm{S}}$ is defined as the maximum emission rate in standardized conditions observed during the season. While first parameterized empirically (Schnitzler et al., 1997), the seasonality function was later related to leaf phenology, temperature sum and light intensity (Lehning et al., 2001). In MEGAN (Guenther et al., 2006), the seasonality in isoprenoid emission rates mainly results from two factors: leaf age and average temperature and light intensity of the past 10 days. Leaf age effect is parameterized assigning different emission capacities to four different leaf age classes - new (emissions not yet induced significantly), growing (emissions below the peak rates), mature (peak emissions) and senescing (emissions below the peak rates) leaves (Guenther et al., 1999, 2000, 2006). On top of the leaf age effects, seasonality also results from temporal changes in average temperature that is used to modify the short-term temperature response function in Eq. (1) as explained in Sect. 2.3. (Guenther et al., 2006). Both the leaf age and leaf temperature function may obtain values above 1 (Guenther et al., 2006), and thus, $E_{\mathrm{S}}$ is differently defined in this model than in the previous Guenther et al. (1991, 1993) algorithms. In this new formulation, $E_{\mathrm{S}}$ is essentially a modeled variable, which cannot be experimentally assessed in field conditions, as it is very hard if possible at all to encounter "standard" medium- to long-term environmental conditions at one field location, let alone at a number of sites. Thus, inverse modeling approaches are commonly employed to yield $E_{\mathrm{S}}$ estimates under standard long-term environmental conditions and leaf age (Guenther et al., 2006).
Alternatively, seasonal variation in the emissions can be directly ascribed to set changes in $E_{\mathrm{S}}$ (Arneth et al., 2008; Geron et al., 2000; Grote et al., 2010; Keenan et al., 2009; Staudt et al., 2000). In such an approach, variation in a measured quantity, the emission rate standardized for immediate variation in environmental drivers (Eq. 1), can be linked to the observed patterns in leaf phenology, and variations in light availability and temperature during the season. Arneth et al. (2008) applied a seasonally varying $E_{\mathrm{S}}$ (expressed as a fraction of electrons used for isoprene production, Niinemets et al., 1999) as a function of growing degree temperature sums, and linked $E_{\mathrm{S}}$ to modeled canopy phenology in spring and autumn. Grote et al. (2010) simulated $E_{\mathrm{S}}$ (determined by the isoprenoid synthase activity) in dependence on leaf phenological state and formation kinetics of isoprenoid synthases empirically fitted to the emission data.

Although mechanistic or semi-mechanistic descriptions linking variations in $E_{\mathrm{S}}$ to leaf developmental status and seasonal modifications in environmental drivers are promising, there are large species-specific variabilities in leaf phenology (Augsburger and Bartlett, 2003; Lechowicz, 1984) and in responsiveness of $E_{\mathrm{S}}$ to seasonal variations in environment (Ekberg et al., 2009). Whenever information of factors controlling the phenological events is lacking, seasonal variations in $E_{\mathrm{S}}$ can be empirically fitted to the data (Fig. 6, Keenan et al., 2009; Staudt et al., 2000).

To our knowledge, different parameterization schemes have been evaluated only in the study of Keenan et al. (2009) who compared the seasonal variations predicted by MEGAN (Guenther et al., 2006), i.e., generalized past weatherdependent response functions for temperature and light combined with a discrete four-level leaf age classification, and by a model using empirical parameterization fitted to the seasonal $E_{\mathrm{S}}$ data (Fig. 5). This model comparison exercise indicated that the MEGAN parameterization predicted weaker seasonality of the emissions than was actually observed (Keenan et al., 2009), indicating that generalized approaches developed to simulate the emissions from any type of vegetation can introduce important bias into seasonal emission estimates if applied in more narrowly specialized applications (any specific type of vegetation, any selected species). Given the importance of seasonality in shaping the annual time-courses of isoprenoid emissions, more experimental information is clearly needed on the species-specific rates of $E_{\mathrm{S}}$ changes during leaf development and senescence, and on the sensitivity of $E_{S}$ to seasonal variations in temperature, light and water availability. As leaf-level seasonal variation studies may be tedious and difficult to replicate, canopy-level flux measurements routinely carried out during the full year may provide an important vehicle for obtaining seasonal variation data (e.g., Ciccioli et al., 2003; Fuentes et al., 1999). 


\subsection{Philosophy of consideration of biological factors in models}

The biogenic volatile compound emission modeling community faces the dilemma that - at least for large scale models - a truly mechanistic approach, e.g., like for photosynthesis modeling (Farquhar et al., 1980), is not yet available. All existing concepts start with a plant's (or plant functional unit's) capacity to emit volatiles under predefined standard conditions $\left(E_{\mathrm{S}}\right)$, and this capacity is then modified up- and downwards based on a number of multiplicative, empirical functions. Originally, $E_{\mathrm{S}}$ was defined as an average emission rate corresponding to arbitrarily defined light intensity and temperature, and emission rates were simulated as the product of $E_{\mathrm{S}}$ and functions describing the instantaneous variations in light and temperature (Eq. 1, Guenther et al., 1991, 1993). As the evidence summarized in Sects. 2.1-2.4 demonstrates, it is not enough to consider only the instantaneous variations in environmental drivers, but also the medium- to long-term environmental and biological controls. Contrasting approaches are currently in use to include these longer-term factors in the isoprenoid emission models.

Guenther et al. $(1999,2000,2006)$ have considered $E_{S}$ at a canopy level as a constant value, and used age-, previous climate and stress dependent multipliers in Eq. (1) to describe the biological effects on the emissions. In Schnitzler et al. (1997) and Lehning et al. (2001), seasonality has been analogously considered as a separate modifier of Eq. (1). In a like manner, Boissard et al. (2008) lumped short and long-term emission controls into a single stochastic emission model. In a simplified way, the emission rate according to these approaches is expressed as:

$E=E_{\mathrm{S}}{ }^{\prime} f$ (short-term) $f$ (long-term),

where $f$ (short-term) refers to instantaneous temperature, light and $C_{\mathrm{i}}$ dependencies as in Eq. (1), while $f$ (long-term) refers to the longer-term dependencies on past temperature ( $\left.T_{\text {past }}\right)$, light intensity $\left(Q_{\text {past }}\right)$ and $\mathrm{CO}_{2}$ concentration $\left(C_{\text {past }}\right)$ and leaf age $(\Lambda)$, and $E_{\mathrm{S}}{ }^{\prime}$ is the emission rate standardized for all these short to long-term controls. $T_{\text {past }}, Q_{\text {past }}$ and $C_{\text {past }}$ each can operate at several time frames to capture day-to-day to seasonal variations and variations during the foliage development (e.g., within-canopy gradients, growth $\mathrm{CO}_{2}$ ). Additional response functions may be needed and are to some extent included (e.g. in MEGAN, Guenther et al., 2006) to consider the effects of various abiotic and biotic stresses on constitutive emissions and predict stress-induced novel emissions (Sect. 2.1).

Differently from this approach, other studies have considered $E_{\mathrm{S}}$ as originally defined by Eq. (1), i.e. an average value standardized only for immediate (short-term) variations in environmental drivers. Thus, $E_{\mathrm{S}}$ varies in dependence on climatic conditions, leaf age and physiological status and growth $\mathrm{CO}_{2}$ environment (Funk et al., 2003; Geron et al., 2000; Gray et al., 2005, 2006; Keenan et al., 2009; Possell et al., 2005; Sharkey et al., 1999). In the latter approach, $E_{\mathrm{S}}$ vs. medium- to longer-term $\left(T_{\text {past }}, Q_{\text {past }}, C_{\text {past }}, \Lambda\right)$ dependencies will be developed for isoprenoid emission modeling purposes:

$E_{\mathrm{S}}=f$ (long-term).

This approach is analogous to widely used models of carbon gain, where short term responses of photosynthesis to environmental drivers are simulated using process-based models, as a rule, Farquhar et al. (1980) photosynthesis model, while modifications in the capacities of the partial processes are studied using acclimation models (Harley and Baldocchi, 1995; Kull, 2002; Niinemets and Anten, 2009; Wilson et al., 2000a,b).

From a modeling perspective both Eqs. (3) and (4) can be parameterized to predict the emission rates with a similar degree of predicted variance (e.g., Fig. 4). However, there is a clear distinction from the experimental perspective and from the perspective of parameterization of the models. According to Eq. (3), $E_{S}{ }^{\prime}$ is standardized not only for immediate fluctuations in environment, but also for longer-term variations, including environmental and leafage-dependent drivers. Thus, one species-specific or canopyspecific value is scaled to different conditions using generalized instantaneous-to-medium-to-long-term environmental algorithms. Equation (3) provides an impression that only one spot measurement is all that is needed. In reality, what is needed is a generalized value that is standardized for variations in all the instantaneous to longer-term factors. In this regard, $E_{\mathrm{S}}{ }^{\prime}$ becomes a modeling concept as it is essentially impossible to simultaneously standardize leaf previous environment, leaf age, and stress status to determine a single species-specific value of $E_{S}^{\prime}$ in the field. Thus, $E_{S}^{\prime}$ must be necessarily derived by inverting the models describing the emission controls at various time-scales.

According to Eq. (4), $E_{\mathrm{S}}$ values are considered inherently variable, emphasizing that repeated sampling is needed to describe this inherent variability. As the "variable $E_{\mathrm{S}}$ " approach separates between the instantaneous effects of light, temperature and internal $\mathrm{CO}_{2}$ concentration on the emission rate (Eq. 1) and the leaf-specific capacity for isoprenoid formation $\left(E_{\mathrm{S}}\right)$ that depends on longer term factors, we encourage the use of this modeling tactic. At any rate, we believe that it is highly important to be aware of these contrasting approaches and also that the emission factors defined by Eqs. (3) and (4) are not the same. With both approaches, the difficulty can be that under field conditions, cumulative weather history, leaf age or "seasonality" factors are often correlated. Thus, care has to be taken to avoid doubleaccounting by adding ever more empirical multipliers into the Guenther-type algorithms or in predicting $E_{\mathrm{S}}$ according to Eq. (4). 


\section{Conclusions and outlook}

A plethora of recent experimental studies has demonstrated that a large number of processes shape variation in $E_{\mathrm{S}}$ on timescales from days to decades, overall indicating that the constancy of $E_{\mathrm{S}}$ values used from study to study is illusion. These major biological sources of variation in $E_{\mathrm{S}}$ values need consideration when examining past experimental and model studies, and the novel information of biological sources of variation in $E_{\mathrm{S}}$ needs to be included more efficiently in the emission models. Here, we have synthesized the existing knowledge about dynamics in $E_{\mathrm{S}}$, with the overall aim to reduce the model uncertainties due to stress, environmental variability, seasonality and foliage developmental stage. We admit that all of these effects cannot be included in a straightforward way into large scale models, partially due to our lack of process understanding, partially because this would lead to over-parameterization of such models. Clearly, inclusion of new response functions into existing large-scale predictive models must go hand-in-hand with experimental work testing the importance of specific biological responses and verifying the more complex models under typical natural settings. While studies on surface-atmosphere interactions have to rely on state-of-the-art source/sink distribution of volatile isoprenoids, they also need to progress on some of the known weaknesses regarding their atmospheric oxidation patterns. In chemistry-climate feedback analyses even the best emission model will be of little value if the chemical reaction pathways are insufficiently described. Separation of first and second-order effects should therefore be a research priority, by quantifying sensitivities of isoprenoid emission model responses to increasing complexity of process description in the emission models themselves, as well as quantifying effects on atmospheric composition.

Acknowledgements. The authors' studies on BVOC emissions have been funded by the Estonian Ministry of Education and Research (grant SF1090065s07), the Estonian Science Foundation (grant 7645), the US National Science Foundation and the US Environmental Protection Agency, the joint collaborative project between Spanish CSIC and the Estonian Academy of Sciences, the Spanish Government (grants CGL2006-04025/BOS and Consolider-Ingenio Montes CSD2008-00040), the Catalan government (grant SGR2009-458), the Human Frontier Science Programme, the Swedish Research Councils VR and Formas. Alex Guenther, Peter Harley, Paolo Ciccioli, Trevor Keenan, Jürgen Kesselmeier and Manuel Lerdau provided invaluable comments and criticism on the earlier versions of this manuscript.

Edited by: C. Spirig

\section{References}

Anderson, L. J., Harley, P. C., Monson, R. K., and Jackson, R. B.: Reduction of isoprene emissions from live oak (Quercus fusiformis) with oak wilt, Tree Physiol., 20, 1199-1203, 2000.

Arneth, A., Miller, P. A., Scholze, M., Hickler, T., Schurgers, G., Smith, B., and Prentice, I. C.: $\mathrm{CO}_{2}$ inhibition of global terrestrial isoprene emissions: potential implications for atmospheric chemistry, Geophys. Res. Lett., 34, L18813, doi:10.1029/2007GL030615, 2007a.

Arneth, A., Niinemets, Ü., Pressley, S., Bäck, J., Hari, P., Karl, T., Noe, S., Prentice, I. C., Serça, D., Hickler, T., Wolf, A., and Smith, B.: Process-based estimates of terrestrial ecosystem isoprene emissions: incorporating the effects of a direct $\mathrm{CO}_{2}$-isoprene interaction, Atmos. Chem. Phys., 7, 31-53, doi:10.5194/acp-7-31-2007, 2007b.

Arneth, A., Schurgers, G., Hickler, T., and Miller, P. A.: Effects of species composition, land surface cover, $\mathrm{CO}_{2}$ concentration and climate on isoprene emissions from European forests, Plant Biol., 10, 150-152, 2008.

Arneth, A. and Niinemets, Ü.: Induced BVOCs: how to bug our models?, Trends Plant Sci., 15, 118-125, 2010.

Asner, G. P., Wessman, C. A., and Archer, S.: Scale dependence of absorption of photosynthetically active radiation in terrestrial ecosystems, Ecol. Appl., 8, 1003-1021, 1998.

Augsburger, C. K. and Bartlett, E. A.: Differences in leaf phenology between juvenile and adult trees in a temperate deciduous forest, Tree Physiol., 23, 517-525, 2003.

Baldocchi, D. D., Wilson, K. B., and Gu, L.: How the environment, canopy structure and canopy physiological functioning influence carbon, water and energy fluxes of a temperate broadleaved deciduous forest - an assessment with the biophysical model CANOAK, Tree Physiol., 22, 1065-1077, 2002.

Baraldi, R., Rapparini, F., Oechel, W. C., Hastings, S. J., Bryant, P., Cheng, Y. F., and Miglietta, F.: Monoterpene emission responses to elevated $\mathrm{CO}_{2}$ in a Mediterranean-type ecosystem, New Phytol., 161, 17-21, 2004.

Bargali, S. S. and Singh, R. P.: Pinus patula plantations in Kumaun Himalaya. I. Dry matter dynamics, J. Trop. For. Sci., 9, 526-535, 1997.

Beauchamp, J., Wisthaler, A., Hansel, A., Kleist, E., Miebach, M., Niinemets, Ü., Schurr, U., and Wildt, J.: Ozone induced emissions of biogenic VOC from tobacco: relations between ozone uptake and emission of LOX products, Plant Cell Environ., 28, 1334-1343, 2005.

Bertin, N. and Staudt, M.: Effect of water stress on monoterpene emissions from young potted holm oak (Quercus ilex L.) trees, Oecologia, 107, 456-462, 1996.

Bertin, N., Staudt, M., Hansen, U., Seufert, G., Ciccioli, P., Foster, P., Fugit, J. L., and Torres, L.: Diurnal and seasonal course of monoterpene emissions from Quercus ilex (L.) under natural conditions - applications of light and temperature algorithms, Atmos. Environ., 31, 135-144, 1997.

Blanch, J.-S., Peñuelas, J., and Llusià, J.: Sensitivity of terpene emissions to drought and fertilization in terpene-storing Pinus halepensis and non-storing Quercus ilex, Physiol. Plant., 131, 211-225, 2007.

Blanch, J.-S., Noe, S. M., Niinemets, Ü., and Peñuelas, J.: Control of plant monoterpene emissions by instantaneous and historical temperatures, J. Environ. Biol., in press, 2010. 
Boissard, C., Cao, X. L., Juan, C. Y., Hewitt, C. N., and Gallagher, M.: Seasonal variations in VOC emission rates from gorse (Ulex europaeus), Atmos. Environ., 35, 917-927, 2001.

Boissard, C., Chervier, F., and Dutot, A. L.: Assessment of high (diurnal) to low (seasonal) frequency variations of isoprene emission rates using a neural network approach, Atmos. Chem. Phys., 8, 2089-2101, doi:10.5194/acp-8-2089-2008, 2008.

Brilli, F., Barta, C., Fortunati, A., Lerdau, M., Loreto, F., and Centritto, M.: Response of isoprene emission and carbon metabolism to drought in white poplar (Populus alba) saplings, New Phytol., 175, 244-254, 2007.

Brilli, F., Ciccioli, P., Frattoni, M., Prestininzi, M., Spanedda, A. F., and Loreto, F.: Constitutive and herbivore-induced monoterpenes emitted by Populus $x$ euroamericana leaves are key volatiles that orient Chrysomela populi beetles, Plant Cell Environ., 32, 542-552, 2009.

Brooks, J. R., Hinckley, T. M., and Sprugel, D. G.: Acclimation responses of mature Abies amabilis sun foliage to shading, Oecologia, 100, 316-324, 1994.

Buckley, P. T.: Isoprene emissions from a Florida scrub oak species grown in ambient and elevated carbon dioxide, Atmos. Environ., 35, 631-634, 2001.

Centritto, M., Nascetti, P., Petrilli, L., Raschi, A., and Loreto, F.: Profiles of isoprene emission and photosynthetic parameters in hybrid poplars exposed to free-air $\mathrm{CO}_{2}$ enrichment, Plant Cell Environ., 27, 403-412, 2004.

Chen, F., Al-Ahmad, H., Joyce, B., Zhao, N., Köllner, T. G., Degenhardt, J., and Stewart Jr., C. N.: Within-plant distribution and emission of sesquiterpenes from Copaifera officinalis, Plant Physiol. Bioch., 47, 1017-1023, 2009.

Ciccioli, P., Fabozzi, C., Brancaleoni, E., Cecinato, A., Frattoni, M., Loreto, F., Kesselmeier, J., Schäfer, L., Bode, K., Torres, L., and Fugit, J.-L.: Use of the isoprene algorithm for predicting the monoterpene emission from the Mediterranean holm oak Quercus ilex L.: performance and limits of this approach, J. Geophys. Res., 102, 23319-23328, 1997.

Ciccioli, P., Brancaleoni, E., Frattoni, M., Brachetti, A., Marta, S., Loreto, F., Seufert, G., Vitullo, M., Tirone, G., Manca, G., and Valentini, R.: Daily and seasonal variations of monoterpene emissions from an evergreen oak (Quercus ilex L.) forest of southern Europe, in: A changing atmosphere: Proceedings of the 8th European symposium on the physico-chemical behaviour of atmospheric pollutants, edited by: Raes, F., Angeletti, G., and Hjorth, J., European Commission, DG Research and Joint Research Center, Ispra, 5 pp., 2001

Ciccioli, P., Brancaleoni, E., Frattoni, M., Marta, S., Brachetti, A., Vitullo, M., Tirone, G., and Valentini, R.: Relaxed eddy accumulation, a new technique for measuring emission and deposition fluxes of volatile organic compounds by capillary gas chromatography and mass spectrometry, J. Chromatogr. A, 985, 283-296, 2003.

Cinege, G., Louis, S., Hänsch, R., and Schnitzler, J.-P.: Regulation of isoprene synthase promoter by environmental and internal factors, Plant Mol. Biol., 69, 593-604, 2009.

Claeys, M., Graham, B., Vas, G., Wang, W., Vermeylen, R., Pashynska, V., Cafmeyer, J., Guyon, P., Andreae, M. O., Artaxo, P., and Maenhaut, W.: Formation of secondary organic aerosols through photooxidation of isoprene, Science, 303, 1173-1176, 2004.
Constable, J. V. H., Litvak, M. E., Greenberg, J. P., and Monson, R. K.: Monoterpene emission from coniferous trees in response to elevated $\mathrm{CO}_{2}$ concentration and climate warming, Global Change Biol., 5, 255-267, 1999.

Curci, G., Beekmann, M., Vautard, R., Smiatek, G., Steinbrecher, R., Theloke, J., and Friedrich, R.: Modelling study of the impact of isoprene and terpene biogenic emissions on European ozone levels, Atmos. Environ., 43, 1444-1455, 2009.

Dicke, M. and Baldwin, I. T.: The evolutionary context for herbivore-induced plant volatiles: beyond the "cry for help", Trends Plant Sci., 15, 167-175, 2010.

Ekberg, A., Arneth, A., Hakola, H., Hayward, S., and Holst, T.: Isoprene emission from wetland sedges, Biogeosciences, 6, 601613, doi:10.5194/bg-6-601-2009, 2009.

Fall, R., Karl, T., Hansel, A., Jordan, A., and Lindinger, W.: Volatile organic compounds emitted after leaf wounding: on-line analysis by proton-transfer-reaction mass spectrometry, J. Geophys. Res., 104, 15963-15974, 1999.

Fang, C., Monson, R. K., and Cowling, E. B.: Isoprene emission, photosynthesis, and growth in sweetgum (Liquidambar styraciflua) seedlings exposed to short- and long-term drying cycles, Tree Physiol., 16, 441-446, 1996.

Fares, S., Barta, C., Brilli, F., Centritto, M., Ederli, L., Ferranti, F., Pasqualini, S., Reale, L., Tricoli, D., and Loreto, F.: Impact of high ozone on isoprene emission, photosynthesis and histology of developing Populus alba leaves directly or indirectly exposed to the pollutant, Physiol. Plant., 128, 456-465, 2006.

Fares, S., Brilli, F., Noguès, I., Velikova, V., Tsonev, T., Dagli, S., and Loreto, F.: Isoprene emission and primary metabolism in Phragmites australis grown under different phosphorus levels, Plant Biol., 10, 38-43, 2008.

Farquhar, G. D., von Caemmerer, S., and Berry, J. A.: A biochemical model of photosynthetic $\mathrm{CO}_{2}$ assimilation in leaves of $\mathrm{C}_{3}$ species, Planta, 149, 78-90, 1980.

Farquhar, G. D. and von Caemmerer, S.: Modeling of photosynthetic response to environmental conditions, in: Physiological Plant Ecology, edited by: Lange, O. L., Nobel, P. S., Osmond, C. B., and Ziegler, H., Encyclopedia of plant physiology, 12B, Springer-Verlag, Berlin, 549-588, 1982.

Fischbach, R. J., Staudt, M., Zimmer, I., Rambal, S., and Schnitzler, J. P.: Seasonal pattern of monoterpene synthase activities in leaves of the evergreen tree Quercus ilex, Physiol. Plant., 114, 354-360, 2002.

Flexas, J. and Medrano, H.: Drought-inhibition of photosynthesis in $\mathrm{C}_{3}$ plants: stomatal and non-stomatal limitations revisited, Ann. Bot., 89, 183-189, 2002.

Fortunati, A., Barta, C., Brilli, F., Centritto, M., Zimmer, I., Schnitzler, J.-P., and Loreto, F.: Isoprene emission is not temperaturedependent during and after severe drought-stress: a physiological and biochemical analysis, Plant J., 55, 687-697, 2008.

Fowler, D., Pilegaard, K., Sutton, M. A., Ambus, P., Raivonen, M., Duyzer, J., Simpson, D., Fagerli, H., Fuzzi, S., Schjoerring, J. K., Granier, C., Neftel, A., Isaksen, I. S. A., Laj, P., Maione, M., Monks, P. S., Burkhardt, J., Daemmgen, U., Neirynck, J., Personne, E., Wichink-Kruit, R., Butterbach-Bahl, K., Flechard, C., Tuovinen, J. P., Coyle, M., Gerosa, G., Loubet, B., Altimir, N., Gruenhage, L., Ammann, C., Cieslik, S., Paoletti, E., Mikkelsen, T. N., Ro-Poulsen, H., Cellier, P., Cape, J. N., Horváth, L., Loreto, F., Niinemets, Ü., Palmer, P. I., Rinne, J., Misztal, P., 
Nemitz, E., Nilsson, D., Pryor, S., Gallagher, M. W., Vesala, T., Skiba, U., Brüggemann, N., Zechmeister-Boltenstern, S., Williams, J., O'Dowd, C., Facchini, M. C., de Leeuw, G., Flossman, A., Chaumerliac, N., and Erisman, J. W.: Atmospheric composition change: ecosystems - atmosphere interactions, Atmos. Environ., 43, 5193-5267, 2009.

Fracheboud, Y., Luquez, V., Björkén, L., Sjödin, A., Tuominen, H., and Jansson, S.: The control of autumn senescence in European aspens (Populus tremula), Plant Physiol., 149, 1982-1991, doi:10.1104/pp.1108.133249, 2009.

Fuentes, J. D. and Wang, D.: On the seasonality of isoprene emissions from a mixed temperate forest, Ecol. Appl., 9, 1118-1131, 1999.

Fuentes, J. D., Wang, D., and Gu, L.: Seasonal variations in isoprene emissions from a boreal aspen forest, J. Appl. Meteorol., 38, 855-869, 1999.

Funk, J. L., Jones, C. G., and Lerdau, M. T.: Defoliation effects on isoprene emission from Populus deltoides, Oecologia, 118, 333-339, 1999.

Funk, J. L., Jones, C. G., Baker, C. J., Fuller, H. M., Giardina, C. P., and Lerdau, M. T.: Diurnal variation in the basal emission rate of isoprene, Ecol. Appl., 13, 269-278, 2003.

Geron, C., Guenther, A., Sharkey, T., and Arnts, R. R.: Temporal variability in basal isoprene emission factor, Tree Physiol., 20, 799-805, 2000.

Gholz, H. L., Vogel, S. A., Cropper Jr., W. P., McKelvey, K., Ewel, K. C., Teskey, R. O., and Curran, P. J.: Dynamics of canopy structure and light interception in Pinus elliottii stands, North Florida, Ecol. Monogr., 61, 33-51, 1991.

Grassi, G. and Magnani, F.: Stomatal, mesophyll conductance and biochemical limitations to photosynthesis as affected by drought and leaf ontogeny in ash and oak trees, Plant Cell Environ., 28, 834-849, 2005

Grassi, G., Vicinelli, E., Ponti, F., Cantoni, L., and Magnani, F.: Seasonal and interannual variability of photosynthetic capacity in relation to leaf nitrogen in a deciduous forest plantation in northern Italy, Tree Physiol., 25, 349-360, 2005.

Gray, D. W., Goldstein, A. H., and Lerdau, M. T.: The influence of light environment on photosynthesis and basal methylbutenol emission from Pinus ponderosa, Plant Cell Environ., 28, 14631474, 2005

Gray, D. W., Goldstein, A. H., and Lerdau, M.: Thermal history regulates methylbutenol basal emission rate in Pinus ponderosa, Plant Cell Environ., 29, 1298-1308, 2006.

Grinspoon, J., Bowman, W. D., and Fall, R.: Delayed onset of isoprene emission in developing velvet bean (Mucuna sp.) leaves, Plant Physiol., 97, 170-174, 1991.

Grote, R., Mayrhofer, S., Fischbach, R. J., Steinbrecher, R., Staudt, M., and Schnitzler, J.-P.: Process-based modelling of isoprenoid emissions from evergreen leaves of Quercus ilex L., Atmos. Environ., 40, S152-S165, 2006.

Grote, R., Lavoir, A.-V., Rambal, S., Staudt, M., Zimmer, I., and Schnitzler, J.-P.: Modelling the drought impact on monoterpene fluxes from an evergreen Mediterranean forest canopy, Oecologia, 160, 213-223, 2009.

Grote, R., Keenan, T., Lavoir, A.-V., and Staudt, M.: Process-based simulation of seasonality and drought stress in monoterpene emission models, Biogeosciences, 7, 257-274, doi:10.5194/bg7-257-2010, 2010.
Guenther, A. B., Monson, R. K., and Fall, R.: Isoprene and monoterpene emission rate variability: observations with $\mathrm{Eu}$ calyptus and emission rate algorithm development, J. Geophys. Res., 96, 10799-10808, 1991.

Guenther, A. B., Zimmerman, P. R., Harley, P. C., Monson, R. K., and Fall, R.: Isoprene and monoterpene emission rate variability: model evaluations and sensitivity analyses, J. Geophys. Res., 98, 12609-12617, 1993.

Guenther, A., Zimmerman, P. R., and Wildermuth, M.: Natural volatile organic compound emission rates for US woodland landscapes, Atmos. Environ., 28, 1197-1210, 1994.

Guenther, A., Hewitt, C. N., Erickson, D., Fall, R., Geron, C., Graedel, T., Harley, P., Klinger, L., Lerdau, M., McKay, W. A., Pierce, T., Scholes, B., Steinbrecher, R., Tallamraju, R., Taylor, J., and Zimmerman, P.: A global model of natural volatile compound emissions, J. Geophys. Res., 100, 8873-8892, 1995.

Guenther, A.: Modeling biogenic volatile organic compound emissions to the atmosphere, in: Reactive hydrocarbons in the atmosphere, edited by: Hewitt, C. N., Academic Press, San Diego, 41-94, 1999.

Guenther, A., Baugh, B., Brasseur, G., Greenberg, J., Harley, P., Klinger, L., Serça, D., and Vierling, L.: Isoprene emission estimates and uncertainties for the Central African EXPRESSO study domain, J. Geophys. Res.-Atmos., 104, 30625-30639, 1999.

Guenther, A., Geron, C., Pierce, T., Lamb, B., Harley, P., and Fall, R.: Natural emissions of non-methane volatile organic compounds, carbon monoxide, and oxides of nitrogen from North America, Atmos. Environ., 34, 2205-2230, 2000.

Guenther, A., Karl, T., Harley, P., Wiedinmyer, C., Palmer, P. I., and Geron, C.: Estimates of global terrestrial isoprene emissions using MEGAN (Model of Emissions of Gases and Aerosols from Nature), Atmos. Chem. Phys., 6, 3181-3210, doi:10.5194/acp-63181-2006, 2006.

Gutschick, V. P.: Plant acclimation to elevated $\mathrm{CO}_{2}$ - from simple regularities to biogeographic chaos, Ecol. Model., 200, 433-451, 2007.

Hall, A. E.: Breeding for heat tolerance, in: Blant breeding reviews, edited by: Janick, J., John Wiley \& Sons, New York, 129-168, 1992.

Hällgren, J.-E., Strand, M., and Lundmark, T.: Temperature stress, in: Physiology of trees, edited by: Raghavendra, A. S., John Wiley \& Sons Inc., New-York, 301-335, 1991.

Hamerlynck, E. P. and Knapp, A. K.: Leaf-level responses to light and temperature in two co-occurring Quercus (Fagaceae) species: implications for tree distribution patterns, Forest Ecol. Manage., 68, 149-159, 1994.

Hanna, S. R., Russell, A. G., Wilkinson, J. G., Vukovich, J., and Hansen, D. A.: Monte Carlo estimation of uncertainties in BEIS3 emission outputs and their effects on uncertainties in chemical transport model predictions, J. Geophys. Res.-Atmos., 110, D01302, doi:10.1029/2004JD004986, 2005.

Hanson, D. T. and Sharkey, T. D.: Rate of acclimation of the capacity for isoprene emission in response to light and temperature, Plant Cell Environ., 24, 937-946, 2001a.

Hanson, D. T. and Sharkey, T. D.: Effect of growth conditions on isoprene emission and other thermotolerance-enhancing compounds, Plant Cell Environ., 24, 929-936, 2001 b. 
Hargreaves, P. R., Leidi, A., Grubb, H. J., Howe, M. T., and Mugglestone, M. A.: Local and seasonal variations in atmospheric nitrogen dioxide levels at Rothamsted, UK, and relationships with meteorological conditions, Atmos. Environ., 34, 843-853, 2000.

Harley, P. C., Litvak, M. E., Sharkey, T. D., and Monson, R. K.: Isoprene emission from velvet bean leaves. Interactions among nitrogen availability, growth photon flux density, and leaf development, Plant Physiol., 105, 279-285, 1994.

Harley, P. C. and Baldocchi, D. D.: Scaling carbon dioxide and water vapour exchange from leaf to canopy in a deciduous forest. I. Leaf model parametrization, Plant Cell Environ., 18, 11461156, 1995.

Harley, P., Guenther, A., and Zimmerman, P.: Effects of light, temperature and canopy position on net photosynthesis and isoprene emission from sweetgum (Liquidambar styraciflua) leaves, Tree Physiol., 16, 25-32, 1996.

Harley, P., Guenther, A., and Zimmerman, P.: Environmental controls over isoprene emission in deciduous oak canopies, Tree Physiol., 17, 705-714, 1997.

Heald, C. L., Henze, D. K., Horowitz, L. W., Feddema, J., Lamarque, J.-F., Guenther, A., Hess, P. G., Vitt, F., Seinfeld, J. H., Goldstein, A. H., and Fung, I.: Predicted change in global secondary organic aerosol concentrations in response to future climate, emissions, and land use change, J. Geophys. Res.-Atmos., 113, D05211, doi:10.1029/2007JD009092, 2008.

Heald, C. L., Wilkinson, M. J., Monson, R. K., Alo, C. A., Wang, G., and Guenther, A.: Response of isoprene emission to ambient $\mathrm{CO}_{2}$ changes and implications for global budgets, Global Change Biol., 15, 1127-1140, 2009.

Heiden, A. C., Kobel, K., Langebartels, C., Schuh-Thomas, G., and Wildt, J.: Emissions of oxygenated volatile organic compounds from plants. Part I: Emissions from lipoxygenase activity, J. Atmos. Chem., 45, 143-172, 2003.

Holopainen, J. K. and Gershenzon, J.: Multiple stress factors and the emission of plant VOCs, Trends Plant Sci., 15, 176-184, 2010.

Huber, D. P. W., Philippe, R. N., Godard, K.-A., Sturrock, R. N., and Böhlmann, J.: Characterization of four terpene synthase cDNAs from methyl jasmonate-induced Douglas-fir, Pseudotsuga menziesii, Phytochemistry, 66, 1427-1439, 2005.

Juuti, S., Arey, J., and Atkinson, R.: Monoterpene emission rate measurements from a Monterey pine, J. Geophys. Res., 95, 7515-7519, 1990.

Kanakidou, M., Seinfeld, J. H., Pandis, S. N., Barnes, I., Dentener, F. J., Facchini, M. C., Van Dingenen, R., Ervens, B., Nenes, A., Nielsen, C. J., Swietlicki, E., Putaud, J. P., Balkanski, Y., Fuzzi, S., Horth, J., Moortgat, G. K., Winterhalter, R., Myhre, C. E. L., Tsigaridis, K., Vignati, E., Stephanou, E. G., and Wilson, J.: Organic aerosol and global climate modelling: a review, Atmos. Chem. Phys., 5, 1053-1123, doi:10.5194/acp-5-1053-2005, 2005.

Karl, T., Guenther, A., Turnipseed, A., Patton, E. G., and Jardine, K.: Chemical sensing of plant stress at the ecosystem scale, Biogeosciences, 5, 1287-1294, doi:10.5194/bg-5-1287-2008, 2008.

Karl, M., Guenther, A., Köble, R., Leip, A., and Seufert, G.: A new European plant-specific emission inventory of biogenic volatile organic compounds for use in atmospheric transport models, Biogeosciences, 6, 1059-1087, doi:10.5194/bg-6-1059-2009, 2009.
Keenan, T., Niinemets, Ü., Sabate, S., Gracia, C., and Peñuelas, J.: Seasonality of monoterpene emission potentials in Quercus ilex and Pinus pinea: Implications for regional BVOC emissions modelling, J. Geophys. Res.-Atmos., 114, D22202, doi:10.1029/2009JD011904, 2009.

Keskitalo, J., Bergquist, G., Gardeström, P., and Jansson, S.: A cellular timetable of autumn senescence, Plant Physiol., 139, 16351648, 2005.

Kesselmeier, J., Bode, K., Hofmann, U., Müller, H., Schäfer, L., Wolf, A., Ciccioli, P., Brancaleoni, E., Cecinato, A., Frattoni, M., Foster, P., Ferrari, C., Jacob, V., Fugit, J. L., Dutaur, L., Simon, V., and Torres, L.: Emission of short chained organic acids, aldehydes and monoterpenes from Quercus ilex L. and Pinus pinea L. in relation to physiological activities, carbon budget and emission algorithms, Atmos. Environ., 31, 119-133, 1997.

Kesselmeier, J., Bode, K., Schäfer, L., Schebeske, G., Wolf, A., Brancaleoni, E., Cecinato, A., Ciccioli, P., Frattoni, M., Dutaur, L., Fugit, J. L., Simon, V., and Torres, L.: Simultaneous field measurements of terpene and isoprene emissions from two dominant Mediterranean oak species in relation to a north American species, Atmos. Environ., 32, 1947-1953, 1998.

Kim, J. C.: Factors controlling natural VOC emissions in a southeastern US pine forest, Atmos. Environ., 35, 3279-3292, 2001.

Kuhn, U., Rottenberger, S., Biesenthal, T., Wolf, A., Schebeske, G., Ciccioli, P., and Kesselmeier, J.: Strong correlation between isoprene emission and gross photosynthetic capacity during leaf phenology of the tropical tree species Hymenaea courbaril with fundamental changes in volatile organic compounds emission composition during early leaf development, Plant Cell Environ., 27, 1469-1485, 2004.

Kull, O.: Acclimation of photosynthesis in canopies: models and limitations, Oecologia, 133, 267-279, 2002.

Kulmala, M., Suni, T., Lehtinen, K. E. J., Dal Maso, M., Boy, M., Reissell, A., Rannik, Ü., Aalto, P., Keronen, P., Hakola, H., Bäck, J., Hoffmann, T., Vesala, T., and Hari, P.: A new feedback mechanism linking forests, aerosols, and climate, Atmos. Chem. Phys., 4, 557-562, doi:10.5194/acp-4-557-2004, 2004.

Lamb, B., Gay, D., Westberg, H., and Pierce, T.: A biogenic hydrocarbon emission inventory for the USA using a simple forest canopy model, Atmos. Environ., 27A, 1673-1690, 1993.

Lavoir, A.-V., Staudt, M., Schnitzler, J. P., Landais, D., Massol, F., Rocheteau, A., Rodriguez, R., Zimmer, I., and Rambal, S.: Drought reduced monoterpene emissions from the evergreen Mediterranean oak Quercus ilex: results from a throughfall displacement experiment, Biogeosciences, 6, 1167-1180, doi:10.5194/bg-6-1167-2009, 2009.

Lechowicz, M. J.: Why do temperate deciduous trees leaf out at different times? Adaptations and ecology of forest communities, Am. Nat., 124, 821-842, 1984.

Lehning, A., Zimmer, W., Zimmer, I., and Schnitzler, J. P.: Modeling of annual variations of oak (Quercus robur L.) isoprene synthase activity to predict isoprene emission rates, J. Geophys. Res., 106, 3157-3166, 2001.

Lenz, R., Selige, T., and Seufert, G.: Scaling up the biogenic emissions from test sites at Castelporziano, Atmos. Environ., 31, 239250, 1997.

Lerdau, M., Litvak, M., and Monson, R.: Monoterpenes and the growth-differentiation balance hypothesis, Tree, 9, 58-61, 1994. 
Lerdau, M., Matson, P., Fall, R., and Monson, R.: Ecological controls over monoterpene emissions from Douglas-fir (Pseudotsuga menziesii), Ecology, 76, 2640-2647, 1995.

Li, D., Chen, Y., Shi, Y., He, X., and Chen, X.: Impact of elevated $\mathrm{CO}_{2}$ and $\mathrm{O}_{3}$ concentrations on biogenic volatile organic compounds emissions from Ginkgo biloba, B. Environ. Contam. Tox., 82, 473-477, 2009.

Litvak, M. E., Loreto, F., Harley, P. C., Sharkey, T. D., and Monson, R. K.: The response of isoprene emission rate and photosynthetic rate to photon flux and nitrogen supply in aspen and white oak trees, Plant Cell Environ., 19, 549-559, 1996.

Litvak, M. E. and Monson, R. K.: Patterns of induced and constitutive monoterpene production in conifer needles in relation to insect herbivory, Oecologia, 114, 531-540, 1998.

Litvak, M. E., Constable, J. V. H., and Monson, R. K.: Supply and demand processes as controls over needle monoterpene synthesis and concentration in Douglas fir [Pseudotsuga menziesii (Mirb.) Franco], Oecologia, 132, 382-391, 2002.

Llorens, L., Llusià, J., Murchie, E. H., Peñuelas, J., and Beerling, D. J.: Monoterpene emissions and photoinhibition of "living fossil" trees grown under $\mathrm{CO}_{2}$ enrichment in a simulated Cretaceous polar environment, J. Geophys. Res.-Biogeo., 114, G01005, doi:10.1029/2008JG000802, 2009.

Llusià, J. and Peñuelas, J.: Changes in terpene content and emission in potted Mediterranean woody plants under severe drought, Can. J. Bot., 76, 1366-1373, 1998.

Llusià, J. and Peñuelas, J.: Seasonal patterns of terpene content and emission from seven Mediterranean woody species in field conditions, Am. J. Bot., 87, 133-140, 2000.

Llusià, J., Peñuelas, J., and Gimeno, B. S.: Seasonal and speciesspecific response of VOC emissions by Mediterranean woody plant to elevated ozone concentrations, Atmos. Environ., 36, 3931-3938 2002.

Llusià, J., Peñuelas, J., Alessio, G. A., and Ogaya, R.: Speciesspecific, seasonal and inter-annual changes in foliar terpene emission rates in Phillyrea latifolia L. and Quercus ilex L. submitted to rain exclusion in the Prades mountains (Catalonia), Russ. J. Plant. Physiol., in press, 2010.

Loivamäki, M., Louis, S., Cinege, G., Zimmer, I., Fischbach, R. J., and Schnitzler, J.-P.: Circadian rhythms of isoprene biosynthesis in grey poplar leaves, Plant Physiol., 143, 540-551, 2007.

Loreto, F. and Sharkey, T. D.: Isoprene emission by plants is affected by transmissible wound signals, Plant Cell Environ., 16, 563-570, 1993.

Loreto, F., Förster, A., Dürr, M., Csiky, O., and Seufert, G.: On the monoterpene emission under heat stress and on the increased thermotolerance of leaves of Quercus ilex L. fumigated with selected monoterpenes, Plant Cell Environ., 21, 101-107, 1998.

Loreto, F., Nascetti, P., Graverini, A., and Mannozzi, M.: Emission and content of monoterpenes in intact and wounded needles of the Mediterranean pine, Pinus pinea, Funct. Ecol., 14, 589-595, 2000.

Loreto, F., Fischbach, R. J., Schnitzler, J. P., Ciccioli, P., Brancaleoni, E., Calfapietra, C., and Seufert, G.: Monoterpene emission and monoterpene synthase activities in the Mediterranean evergreen oak Quercus ilex L. grown at elevated $\mathrm{CO}_{2}$, Global Change Biol., 7, 709-717, 2001.

Loreto, F. and Velikova, V.: Isoprene produced by leaves protects the photosynthetic apparatus against ozone damage, quenches ozone products, and reduces lipid peroxidation of cellular membranes, Plant Physiol., 127, 1781-1787, 2001.

Loreto, F., Pinelli, P., Manes, F., and Kollist, H.: Impact of ozone on monoterpene emissions and evidence for an isoprene-like antioxidant action of monoterpenes emitted by Quercus ilex leaves, Tree Physiol., 24, 361-367, 2004.

Loreto, F., Barta, C., Brilli, F., and Nogues, I.: On the induction of volatile organic compound emissions by plants as consequence of wounding or fluctuations of light and temperature, Plant Cell Environ., 29, 1820-1828, 2006.

Loreto, F. and Schnitzler, J.-P.: Abiotic stresses and induced BVOCs, Trends Plant Sci., 15, 154-166, 2010.

Martin, M. J., Stirling, C. M., Humphries, S. W., and Long, S. P.: A process-based model to predict the effects of climatic change on leaf isoprene emission rates, Ecol. Model., 131, 161-174, 2000.

Mayrhofer, S., Teuber, M., Zimmer, I., Louis, S., Fischbach, R. J., and Schnitzler, J.-P.: Diurnal and seasonal variation of isoprene biosynthesis-related genes in grey poplar leaves, Plant Physiol., 139, 474-484, 2005.

McMurtrie, R. E. and Comins, H. N.: The temporal response of forest ecosystems to doubled atmospheric $\mathrm{CO}_{2}$ concentration, Global Change Biol., 2, 49-57, 1996.

Medrano, H., Escalona, J. M., Bota, J., Gulias, J., and Flexas, J.: Regulation of photosynthesis of $\mathrm{C}_{3}$ plants in response to progressive drought: Stomatal conductance as a reference parameter, Ann. Bot., 89, 895-905, 2002.

Mentel, Th. F., Wildt, J., Kiendler-Scharr, A., Kleist, E., Tillmann, R., Dal Maso, M., Fisseha, R., Hohaus, Th., Spahn, H., Uerlings, R., Wegener, R., Griffiths, P. T., Dinar, E., Rudich, Y., and Wahner, A.: Photochemical production of aerosols from real plant emissions, Atmos. Chem. Phys., 9, 4387-4406, doi:10.5194/acp9-4387-2009, 2009.

Monson, R. K., Harley, P. C., Litvak, M. E., Wildermuth, M., Guenther, A. B., Zimmerman, P. R., and Fall, R.: Environmental and developmental controls over the seasonal pattern of isoprene emission from aspen leaves, Oecologia, 99, 260-270, 1994.

Monson, R. K., Trahan, N., Rosenstiel, T. N., Veres, P., Moore, D., Wilkinson, M., Norby, R. J., Volder, A., Tjoelker, M. G., Briske, D. D., Karnosky, D. F., and Fall, R.: Isoprene emission from terrestrial ecosystems in response to global change: minding the gap between models and observations, Philos. T. Roy. Soc. Lond. A, 365, 1677-1695, 2007.

Niinemets, Ü., Tenhunen, J. D., Harley, P. C., and Steinbrecher, R.: A model of isoprene emission based on energetic requirements for isoprene synthesis and leaf photosynthetic properties for Liquidambar and Quercus, Plant Cell Environ., 22, 13191336, 1999.

Niinemets, Ü., Hauff, K., Bertin, N., Tenhunen, J. D., Steinbrecher, R., and Seufert, G.: Monoterpene emissions in relation to foliar photosynthetic and structural variables in Mediterranean evergreen Quercus species, New Phytol., 153, 243-256, 2002a.

Niinemets, Ü., Seufert, G., Steinbrecher, R., and Tenhunen, J. D.: A model coupling foliar monoterpene emissions to leaf photosynthetic characteristics in Mediterranean evergreen Quercus species, New Phytol., 153, 257-276, 2002b.

Niinemets, Ü., Kull, O., and Tenhunen, J. D.: Within canopy variation in the rate of development of photosynthetic capacity is proportional to integrated quantum flux density in temperate deciduous trees, Plant Cell Environ., 27, 293-313, 2004. 
Niinemets, Ü. and Valladares, F.: Photosynthetic acclimation to simultaneous and interacting environmental stresses along natural light gradients: optimality and constraints, Plant Biol., 6, 254268, 2004

Niinemets, Ü., Cescatti, A., Rodeghiero, M., and Tosens, T.: Complex adjustments of photosynthetic capacity and internal mesophyll conductance to current and previous light availabilities and leaf age in Mediterranean evergreen species Quercus ilex, Plant Cell Environ., 29, 1159-1178, 2006.

Niinemets, Ü.: Photosynthesis and resource distribution through plant canopies, Plant Cell Environ., 30, 1052-1071, 2007.

Niinemets, Ü. and Valladares, F.: Environmental tolerance, in: Encyclopedia of Ecology, edited by: Jørgensen, S. E. and Fath, B. D., Elsevier, Oxford, 1370-1376, 2008.

Niinemets, Ü. and Anten, N. P. R.: Packing photosynthesis machinery: from leaf to canopy, in: Photosynthesis in silico: understanding complexity from molecules to ecosystems, 29 edition, edited by: Laisk, A., Nedbal, L., and Govindjee, Advances in photosynthesis and respiration, Springer Verlag, Berlin, 363399, 2009.

Niinemets, Ü.: Mild versus severe stress and BVOCs: thresholds, priming and consequences, Trends Plant Sci., 15, 145-153, 2010.

Niinemets, Ü., García-Plazaola, J. I., and Tosens, T.: Photosynthesis during leaf development and ageing, in: Terrestrial photosynthesis in a changing environment, The molecular, physiological and ecological bases of photosynthesis driving its response to the environmental changes, edited by: Flexas, J., Loreto, F., and Medrano, H., Cambridge University Press, Cambridge, in press, 2010a.

Niinemets, Ü., Monson, R. K., Arneth, A., Ciccioli, P., Kesselmeier, J., Kuhn, U., Noe, S. M., Peñuelas, J., and Staudt, M.: The leaflevel emission factor of volatile isoprenoids: caveats, model algorithms, response shapes and scaling, Biogeosciences, 7, 18091832, doi:10.5194/bg-7-1809-2010, 2010b.

Ortega, J. and Helmig, D.: Approaches for quantifying reactive and low-volatility biogenic organic compound emissions by vegetation enclosure techniques - Part A, Chemosphere, 72, 343-364, 2008.

Ortega, J., Helmig, D., Daly, R. W., Tanner, D. M., Guenther, A. B., and Herrick, J. D.: Approaches for quantifying reactive and low-volatility biogenic organic compound emissions by vegetation enclosure techniques - Part B: applications, Chemosphere, 72, 365-380, 2008.

Owen, S., Boissard, C., Street, R. A., Duckham, S. C., Csiky, O., and Hewitt, C. N.: Screening of 18 Mediterranean plant species for volatile organic compound emissions, Atmos. Environ., 31, 101-117, 1997.

Pegoraro, E., Rey, A., Bobich, E. G., Barron-Gafford, G. A., Grieve, K. A., Malhi, Y., and Murthy, R.: Effect of elevated $\mathrm{CO}_{2}$ concentration and vapor pressure deficit on isoprene emission from leaves of Populus deltoides during drought, Funct. Plant Biol., 31, 1137-1147, 2004a.

Pegoraro, E., Rey, A., Greenberg, J., Harley, P., Grace, J., Malhi, Y., and Guenther, A.: Effect of drought on isoprene emission rates from leaves of Quercus virginiana Mill., Atmos. Environ., 38, 6149-6156, 2004b.

Pegoraro, E., Rey, A., Barron-Gafford, G., Monson, R., Malh, Y., and Murthy, R.: The interacting effects of elevated atmospheric $\mathrm{CO}_{2}$ concentration, drought and leaf-to-air vapour pressure deficit on ecosystem isoprene fluxes, Oecologia, 146, 120-129, 2005.

Peñuelas, J. and Llusià, J.: Effects of carbon dioxide, water supply, and seasonality on terpene content and emission by Rosmarinus officinalis, J. Chem. Ecol., 23, 979-993, 1997.

Peñuelas, J. and Estiarte, M.: Can elevated $\mathrm{CO}_{2}$ affect secondary metabolism and ecosystem functioning?, Tree, 13, 20-24, 1998.

Peñuelas, J. and Llusià, J.: BVOCs: plant defense against climatic warming?, Trends Plant Sci., 8, 105-109, 2003.

Peñuelas, J., Filella, I., Stefanescu, C., and Llusià, J.: Caterpillars of Euphydryas aurinia (Lepidoptera: Nymphalidae) feeding on Succisa pratensis leaves induce large foliar emissions of methanol, New Phytol., 167, 851-857, 2005.

Peñuelas, J., Filella, I., Seco, R., and Llusià, J.: Increase in isoprene and monoterpene emissions after re-watering of droughted Quercus ilex seedlings, Biol. Plant., 53, 351-354, 2009.

Peñuelas, J. and Staudt, M.: BVOCs and global change, Trends Plant Sci., 15, 133-144, 2010.

Pétron, G., Harley, P., Greenberg, J., and Guenther, A.: Seasonal temperature variations influence isoprene emission, Geophys. Res. Lett., 28, 1707-1710, 2001.

Pook, E. W.: Canopy dynamics of Eucalyptus maculata Hook, I. Distribution and dynamics of leaf populations, Aust. J. Bot., 32, 387-403, 1984.

Porcar-Castell, A., Peñuelas, J., Owen, S. M., Llusià, J., MunnéBosch, S., and Bäck, J.: Leaf carotenoid concentrations and monoterpene emission capacity under acclimation of the light reactions of photosynthesis, Boreal Environ. Res., 14, 794-806, 2009.

Possell, M., Heath, J., Hewitt, C. N., Ayres, E., and Kerstiens, G.: Interactive effects of elevated $\mathrm{CO}_{2}$ and soil fertility on isoprene emissions from Quercus robur, Global Change Biol., 10, 18351843, 2004.

Possell, M., Hewitt, C. N., and Beerling, D. J.: The effects of glacial atmospheric $\mathrm{CO}_{2}$ concentrations and climate on isoprene emissions by vascular plants, Global Change Biol., 11, 60-69, 2005.

Priemé, A., Knudsen, T. B., Glasius, M., and Christensen, S.: Herbivory by the weevil, Strophosoma melanogrammum, causes severalfold increase in emission of monoterpenes from young Norway spruce (Picea abies), Atmos. Environ., 34, 711-718, 2000.

Räisänen, T., Ryyppö, A., Julkunen-Tiitto, R., and Kellomäki, S.: Effects of elevated $\mathrm{CO}_{2}$ and temperature on secondary compounds in the needles of Scots pine (Pinus sylvestris L.), Trees, 22, 121-135, 2008a.

Räisänen, T., Ryyppö, A., and Kellomäki, S.: Effects of elevated $\mathrm{CO}_{2}$ and temperature on monoterpene emission of Scots pine (Pinus sylvestris L.), Atmos. Environ., 42, 4160-4171, $2008 \mathrm{~b}$.

Rapparini, F., Baraldi, R., Miglietta, F., and Loreto, F.: Isoprenoid emission in trees of Quercus pubescens and Quercus ilex with lifetime exposure to naturally high $\mathrm{CO}_{2}$ environment, Plant Cell Environ., 27, 381-391, 2004.

Reynolds, J. F., Kemp, P. R., Acock, B., Chen, J.-L., and Moorhead, D. L.: Progress, limitations, and challenges in modeling the effects of elevated $\mathrm{CO}_{2}$ on plants and ecosystems, in: Carbon dioxide and terrestrial ecosystems, edited by: Koch, G. W. and Mooney, H. A., Academic Press, Inc., San Diego, 347-380, 1996.

Rosenstiel, T. N., Potosnak, M. J., Griffin, K. L., Fall, R., and Monson, R. K.: Increased $\mathrm{CO}_{2}$ uncouples growth from isoprene 
emission in an agriforest ecosystem, Nature, 421, 256-259, 2003.

Rosenthal, S. I. and Camm, E. L.: Effects of air temperature, photoperiod and leaf age on foliar senescence of western larch (Larix occidentalis Nutt.) in environmentally controlled chambers, Plant Cell Environ., 19, 1057-1065, 1996.

Rosenthal, S. I. and Camm, E. L.: Photosynthetic decline and pigment loss during autumn foliar senescence in western larch (Larix occidentalis), Tree Physiol., 17, 767-775, 1997.

Sabillón, D. and Cremades, L. V.: Diurnal and seasonal variation of monoterpene emission rates for typical Mediterranean species (Pinus pinea and Quercus ilex) from field measurements - relationship with temperature and PAR, Atmos. Environ., 35, 44194431, 2001.

Schade, G. W. and Goldstein, A. H.: Increase of monoterpene emissions from a pine plantation as a result of mechanical disturbances, Geophys. Res. Lett., 30, 1380, doi:10.1029/2002GL016138, 2003.

Schnitzler, J. P., Lehning, A., and Steinbrecher, R.: Seasonal pattern of isoprene synthase activity in Quercus robur leaves and its significance for modeling isoprene emission rates, Bot. Acta, 110, 240-243, 1997.

Scholefield, P. A., Doick, K. J., Herbert, B., Hewitt, C. N., Schnitzler, J. P., Pinelli, P., and Loreto, F.: Impact of rising $\mathrm{CO}_{2}$ on VOC emissions: isoprene emission from Phragmites australis growing at elevated $\mathrm{CO}_{2}$ in a natural carbon dioxide spring, Plant Cell Environ., 27, 393-401, 2004.

Sharkey, T. D. and Seemann, J. R.: Mild water stress effects on carbon-reduction-cycle intermediates, ribulose bisphosphate carboxylase activity, and spatial homogeneity of photosynthesis in intact leaves, Plant Physiol., 89, 1060-1065, 1989.

Sharkey, T. D., Loreto, F., and Delwiche, C. F.: High carbon dioxide and sun/shade effects on isoprene emission from oak and aspen tree leaves, Plant Cell Environ., 14, 333-338, 1991.

Sharkey, T. D. and Loreto, F.: Water stress, temperature, and light effects on the capacity for isoprene emission and photosynthesis of kudzu leaves, Oecologia, 95, 328-333, 1993.

Sharkey, T. D., Singsaas, E. L., Vanderveer, P. J., and Geron, C.: Field measurements of isoprene emission from trees in response to temperature and light, Tree Physiol., 16, 649-654, 1996.

Sharkey, T. D., Singsaas, E. L., Lerdau, M. T., and Geron, C. D.: Weather effects on isoprene emission capacity and applications in emissions algorithms, Ecol. Appl., 9, 1132-1137, 1999.

Sharkey, T. D.: Effects of moderate heat stress on photosynthesis: importance of thylakoid reactions, rubisco deactivation, reactive oxygen species, and thermotolerance provided by isoprene, Plant Cell Environ., 28, 269-277, 2005.

Shesták, Z., Tichá, I., Chatsky, J., Solárová, J., Pospíshilová, J., and Hodánová, D.: Integration of photosynthetic characteristics during leaf development, in: Photosynthesis during leaf development, edited by: Shesták, Z., Tasks for vegetation science, 11, Dr. W. Junk Publishers, Dordrecht - Boston - Lancaster, 263286, 1985.

Simon, E., Kuhn, U., Rottenberger, S., Meixner, F. X., and Kesselmeier, J.: Coupling isoprene and monoterpene emissions from Amazonian tree species with physiological and environmental parameters using a neural network approach, Plant Cell Environ., 28, 287-301, 2005.
Simpson, D., Guenther, A., Hewitt, C. N., and Steinbrecher, R.: Biogenic emissions in Europe. 1. Estimates and uncertainties, J. Geophys. Res., 100, 22875-22890, 1995.

Simpson, D., Winiwarter, W., Börjesson, G., Cinderby, S., Ferreiro, A., Guenther, A., Hewitt, C. N., Janson, R., Khalil, M. A. K., Owen, S., Pierce, T. E., Puxbaum, H., Shearer, M., Skiba, U., Steinbrecher, R., Tarrasón, L., and Öquist, M. G.: Inventorying emissions from nature in Europe, J. Geophys. Res.-Atmos., 104, 8113-8152, 1999.

Singsaas, E. L., Laporte, M. M., Shi, J.-Z., Monson, R. K., Bowling, D. R., Johnson, K., Lerdau, M., Jasentuliytana, A., and Sharkey, T. D.: Kinetics of leaf temperature fluctuation affect isoprene emission from red oak (Quercus rubra) leaves, Tree Physiol., 19, 917-924, 1999.

Singsaas, E. L. and Sharkey, T. D.: The effects of high temperature on isoprene synthesis in oak leaves, Plant Cell Environ., 23, 751757, 2000.

Snow, M. D., Bard, R. R., Olszyk, D. M., Minster, L. M., Hager, A. N., and Tingey, D. T.: Monoterpene levels in needles of Douglas fir exposed to elevated $\mathrm{CO}_{2}$ and temperature, Physiol. Plant., 117, 352-358, 2003.

Spracklen, D. V., Bonn, B., and Carslaw, K. S.: Boreal forests, aerosols and the impacts on clouds and climate, Philos. T. Roy. Soc. Lond. A, 366, 4613-4626, 2008.

Staudt, M. and Bertin, N.: Light and temperature dependence of the emission of cyclic and acyclic monoterpenes from holm oak (Quercus ilex L.) leaves, Plant Cell Environ., 21, 385-395, 1998.

Staudt, M., Bertin, N., Frenzel, B., and Seufert, G.: Seasonal variation in amount and composition of monoterpenes emitted by young Pinus pinea trees - implications for emission modeling, J. Atmos. Chem., 35, 77-99, 2000.

Staudt, M., Joffre, R., Rambal, S., and Kesselmeier, J.: Effect of elevated $\mathrm{CO}_{2}$ on monoterpene emission of young Quercus ilex trees and its relation to structural and ecophysiological parameters, Tree Physiol., 21, 437-445, 2001.

Staudt, M., Rambal, S., Joffre, R., and Kesselmeier, J.: Impact of drought on seasonal monoterpene emissions from Quercus ilex in southern France, J. Geophys. Res., D107, 4602, doi:10.1029/2001JD002043, 2002.

Staudt, M., Joffre, R., and Rambal, S.: How growth conditions affect the capacity of Quercus ilex leaves to emit monoterpenes, New Phytol., 158, 61-73, 2003.

Staudt, M., Mir, C., Joffre, R., Rambal, S., Bonin, A., Landais, D., and Lumaret, R.: Isoprenoid emissions of Quercus spp. (Q. suber and $Q$. ilex) in mixed stands contrasting in interspecific genetic introgression, New Phytol., 163, 573-584, 2004.

Staudt, M. and Lhoutellier, L.: Volatile organic compound emission from holm oak infested by gypsy moth larvae: evidence for distinct responses in damaged and undamaged leaves, Tree Physiol., 27, 1433-1440, 2007.

Staudt, M., Ennajah, A., Mouillot, F., and Joffre, R.: Do volatile organic compound emissions of Tunisian cork oak populations originating from contrasting climatic conditions differ in their responses to summer drought?, Can. J. Forest Res., 38, 29652975, 2008.

Steinbrecher, R., Smiatek, G., Köble, R., Seufert, G., Theloke, J., Hauff, K., Ciccioli, P., Vautard, R., and Curci, G.: Intra- and inter-annual variability of VOC emissions from natural and seminatural vegetation in Europe and neighbouring countries, Atmos. 
Environ., 43, 1380-1391, 2009.

Steindel, F., Beauchamp, J., Hansel, A., Kesselmeier, J., Kleist, E., Kuhn, U., Wisthaler, A., and Wildt, J.: Stress induced VOC emissions from mildew infested oak, Geophys. Res. Abstracts, 7, EGU05-A-03010, 2005.

Stolwijk, A. M., Straatman, H., and Zielhuis, G. A.: Studying seasonality by using sine and cosine functions in regression analysis, J. Epidemiol. Commun. H., 53, 235-238, 1999.

Street, R. A., Owen, S., Duckham, S. C., Boissard, C., and Hewitt, C. N.: Effect of habitat and age on variations in volatile organic compound (VOC) emissions from Quercus ilex and Pinus pinea, Atmos. Environ., 31, 89-100, 1997.

Sun, Z., Niinemets, Ü., and Copolovici, L.: Foliar isoprene emission during autumn senescence in aspen (Populus tremula), Geochim. Cosmochim. Ac., 73, A1295, doi:10.1016/j.gca.2009.05.015, 2009.

Tingey, D. T., Turner, D. P., and Weber, J. A.: Factors controlling the emissions of monoterpenes and other volatile organic compounds, in: Trace gas emissions by plants, edited by: Sharkey, T. D., Holland, E. A., and Mooney, H. A., Physiological ecology, A series of monographs, texts, and treatises, Academic Press, Inc., San Diego/New York/Boston/London/Sydney/Tokyo/Toronto, 93-119, 1991.

Tognetti, R., Johnson, J. D., Michelozzi, M., and Raschi, A.: Response of foliar metabolism in mature trees of Quercus pubescens and Quercus ilex to long-term elevated $\mathrm{CO}_{2}$, Environ. Exp. Bot., 39, 233-245, 1998.

Valladares, F. and Niinemets, Ü.: The architecture of plant crowns: from design rules to light capture and performance, in: Handbook of functional plant ecology, 2nd edition, edited by: Pugnaire, F. I. and Valladares, F., CRC Press, Boca Raton, 101-149, 2007.

van Doorn, W. G. and Woltering, E. J.: Senescence and programmed cell death: substance or semantics?, J. Exp. Bot., 55, 2147-2153, 2004.

Velikova, V., Tsonev, T., Pinelli, P., Alessio, G. A., and Loreto, F.: Localized ozone fumigation system for studying ozone effects on photosynthesis, respiration, electron transport rate and isoprene emission in field-grown Mediterranean oak species, Tree Physiol., 25, 1523-1532, 2005.

Vickers, C. E., Gershenzon, J., Lerdau, M. T., and Loreto, F.: A unified mechanism of action for volatile isoprenoids in plant abiotic stress, Nat. Chem. Biol., 5, 283-291, 2009.

Wiberley, A. E., Linskey, A. R., Falbel, T. G., and Sharkey, T. D.: Development of the capacity for isoprene emission in kudzu, Plant Cell Environ., 28, 898-905, 2005.

Wiberley, A. E., Donohue, A. R., Meier, M. E., Westphal, M. M., and Sharkey, T. D.: Regulation of isoprene emission in Populus trichocarpa leaves subjected to changing growth temperature, Plant Cell Environ., 31, 258-267, 2008.
Wiedinmyer, C., Greenberg, J., Guenther, A., Hopkins, B., Baker, K., Geron, C., Palmer, P. I., Long, B. P., Turner, J. R., Pétron, G., Harley, P., Pierce, T. E., Lamb, B., Westberg, H., Baugh, W., Koerber, M., and Janssen, M.: Ozarks Isoprene Experiment (OZIE): measurements and modeling of the "isoprene volcano", J. Geophys. Res.-Atmos., 110, D18307, doi:10.1029/2005JD005800, 2005.

Wilkinson, M. J., Owen, S. M., Possell, M., Hartwell, J., Gould, P., Hall, A., Vickers, C., and Hewitt, C. N.: Circadian control of isoprene emissions from oil palm (Elaeis guineensis), Plant J., 47, 960-968, 2006.

Wilkinson, M. J., Monson, R. K., Trahan, N., Lee, S., Brown, E., Jackson, R. B., Polley, H. W., Fay, P. A., and Fall, R.: Leaf isoprene emission rate as a function of atmospheric $\mathrm{CO}_{2}$ concentration, Global Change Biol., 15, 1189-1200, 2009.

Wilson, K. B., Baldocchi, D. D., and Hanson, P. J.: Quantifying stomatal and non-stomatal limitations to carbon assimilation resulting from leaf aging and drought in mature deciduous tree species, Tree Physiol., 20, 787-797, 2000a.

Wilson, K. B., Baldocchi, D. D., and Hanson, P. J.: Spatial and seasonal variability of photosynthetic parameters and their relationship to leaf nitrogen in a deciduous forest, Tree Physiol., 20, 565-578, 2000b.

Wilson, K. B., Baldocchi, D. D., and Hanson, P. J.: Leaf age affects the seasonal pattern of photosynthetic capacity and net ecosystem exchange of carbon in a deciduous forest, Plant Cell Environ., 24, 571-583, 2001.

Yani, A., Pauly, G., Faye, M., Salin, F., and Gleizes, M.: The effect of a long-term water stress on the metabolism and emission of terpenes of the foliage of Cupressus sempervirens, Plant Cell Environ., 16, 975-981, 1993.

Young, P. J., Arneth, A., Schurgers, G., Zeng, G., and Pyle, J. A.: The $\mathrm{CO}_{2}$ inhibition of terrestrial isoprene emission significantly affects future ozone projections, Atmos. Chem. Phys., 9, 27932803, doi:10.5194/acp-9-2793-2009, 2009.

Zhang, R., Cruz, J. A., Kramer, D. M., Magallanes-Lundback, M. E., DellaPenna, D., and Sharkey, T. D.: Moderate heat stress reduces the $\mathrm{pH}$ component of the transthylakoid proton motive force in light-adapted, intact tobacco leaves, Plant Cell Environ., 32, 1538-1547, 2009.

Zhang, R. and Sharkey, T. D.: Photosynthetic electron transport and proton flux under moderate heat stress, Photosynth. Res., 100, 29-43, 2009.

Zimmer, W., Brüggemann, N., Emeis, S., Giersch, C., Lehning, A., Steinbrecher, R., and Schnitzler, J. P.: Process-based modelling of isoprene emission by oak leaves, Plant Cell Environ., 23, 585595, 2000. 